\title{
Foreign Currency Borrowing by Small Firms
}

Martin Brown, Steven Ongena and Pinar Yeșin

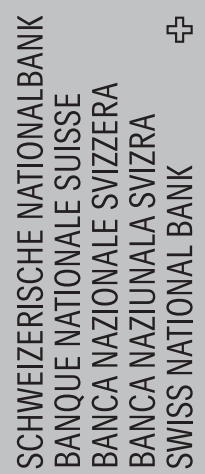

บ

(4)

O

ro

ก

$\frac{0}{2}$

ro

a

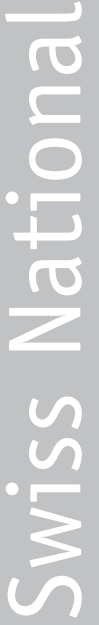


The views expressed in this paper are those of the author(s) and do not necessarily represent those of the Swiss National Bank. Working Papers describe research in progress. Their aim is to elicit comments and to further debate.

ISSN 1660-7716 (printed version)

ISSN 1660-7724 (online version)

๑ 2009 by Swiss National Bank, Börsenstrasse 15, P.0. Box, CH-8022 Zurich 


\title{
Foreign Currency Borrowing by Small Firms
}

\author{
Martin Brown*, Steven Ongena**, Pinar Yeşin***
}

February 2009

* Swiss National Bank, email: martin.brown@ @nb.ch, ** CentER - Tilburg University and CEPR, email: steven.ongena@tilburguniversity.nl, ***Swiss National Bank, email: pinar.yesin@snb.ch.

This paper has previously been circulated under the title "Currency Denomination of Bank Loans: Evidence from Small Firms in Transition Countries." We thank Raphael Auer, Henrique Basso, Katalin Bodnar, Andreas Fischer, Davide Furceri, Luigi Guiso, Werner Hermann, Herman Kamil, Anton Korinek, Marcel Peter, Maria Rueda Mauer, Philip Sauré, Clas Wihlborg and seminar participants at the University of Amsterdam, the Federal Reserve Bank of Boston, the Swiss National Bank, as well as participants at the SNB-CEPR conference on "Foreign Currency Risk Taking by Financial Institutions, Firms and Households" (Zürich), the European Economic Association Meetings (Milano), ESCE Meetings (Paris), and the Tor Vergata Banking and Finance Conference (Rome) for useful comments and discussions. We also thank Simon Wehrmueller for valuable research assistance. Ongena gratefully acknowledges the hospitality of the Swiss National Bank. Any views expressed are those of the authors and do not necessarily reflect those of the Swiss National Bank. 


\title{
Foreign Currency Borrowing by Small Firms
}

\begin{abstract}
We examine the firm- and country-level determinants of the currency denomination of small business loans. We first model the choice of loan currency in a framework which features a trade-off between lower cost of debt and the risk of firm-level distress costs, and also examines the impact of information asymmetry between banks and firms. When foreign currency funds come at a lower interest rate, all foreign currency earners as well as those local currency earners with high revenues and low distress costs choose foreign currency loans. When the banks have imperfect information on the currency and level of firms revenues, even more local earners switch to foreign currency loans, as they do not bear the full cost of the corresponding credit risk.

We then test the implications of our model by using a 2005 survey with responses from 9,655 firms in 26 transition countries. The survey contains details on 3,105 recent bank loans. At the firm level, our findings suggest that firms with foreign currency income and assets are more likely to borrow in a foreign currency. In contrast, firm-level distress costs and financial transparency affect the currency denomination only weakly. At the country level, the interest rate advantages of foreign currency funds and the exchange rate volatility do not explain the foreign currency borrowing in our sample. However, foreign bank presence, weak corporate governance and the absence of capital controls encourage foreign currency borrowing. All in all, we cannot confirm that "carry-trade behavior" is the key driver of foreign currency borrowing by small firms in transition economies. Our results do, however, support the conjecture that banking-sector structures and institutions that aggravate information asymmetries may facilitate foreign currency borrowing.
\end{abstract}

Keywords: foreign currency borrowing, competition, banking sector, market structure.

JEL: G21, G30, F34, F37. 


\section{Introduction}

A large proportion of firms and households in many countries borrow in foreign currency. In East Asia, corporate debt is split about equally between foreign and domestic currencies (Allayannis, Brown and Klapper (2003)), while in several Latin American countries the share of foreign currency debt exceeds 20 percent (Galindo, Panizza and Schiantarelli (2003)). Recently, foreign currency borrowing has also expanded rapidly in many Eastern European transition countries. Between 20 and 75 percent of all corporate loans in Eastern European countries are now denominated in a foreign currency (European Central Bank (2006), p. 39).

Foreign currency borrowing is widely alleged to be one of the major causes of the severe financial crisis that hit many Asian countries in the 1990's. Foreign currency borrowing in Eastern Europe could similarly lead to widespread credit default and the destabilization of the entire banking sector there if the current global financial crisis involves further sharp depreciations of local currencies (as was the case, for example, with the Hungarian forint and Polish zloty in the fall of 2008).

Indeed, there are fears that many small non-exporting firms and households in Eastern Europe may have taken out commercial loans and mortgages in euros - or even in Swiss francs and Japanese yen - in order to benefit from the substantially lower interest rate on the foreign currency (clearly the expected introduction of the euro and increasing trade flows also explain some of the loan currency choices). ${ }^{1}$ These "small men's carry trades"

\footnotetext{
${ }^{1}$ Wall Street Journal, May $29^{\text {th }}$, 2007. Carry trades, in which investors borrow in a low-yielding currency and invest in a high-yielding one, are a widespread phenomenon. At the beginning of 2007 it was estimated that that as much as US\$1 trillion was involved in the yen carry trade for example (The Economist, February $1^{\text {st }}$, 2007). Traditionally, carry trades have been made by large financial institutions and leveraged institutions, such as hedge funds. Low exchange rate volatility and persistent interest rate differentials have fueled the growth in cross-currency positions in recent years (Galati, Heath and McGuire (2007)).
} 
have raised concerns about the resulting credit risks, especially in those situations where financiers are unable to assess the actual foreign currency needs of their borrowers. Indeed, a 2007 Report by the International Monetary Fund (Sorsa, Bakker, Duenwald, Maechler and Tiffin (2007)) warned that

"Corporate foreign currency debt in (emerging) Europe is at levels similar to pre-crisis Asia and Latin America [... and] currency risks are amplified because much of the corporate foreign currency exposure seems unhedged. [...] The drive of [foreign] banks to complement limited earnings opportunities at home with high profits from emerging Europe may have led to risk under-pricing. [...] This under-pricing may be compounded by limited data on creditworthiness and weak institutions."

The recent increase in foreign currency borrowing in Eastern Europe and the widespread policy concerns resulting therefrom have drawn considerable interest from academics and policy makers alike. However, all studies so far (to the best of our knowledge) have analyzed foreign currency borrowing at either the aggregate or the bank level. ${ }^{2}$ These studies therefore cannot determine the extent to which foreign currency borrowing is carried out by firms or households. In contrast, this paper examines the currency denomination of individual retail loans in virtually all transition countries of Eastern Europe and the former Soviet Union. In particular, we focus on lending to small

\footnotetext{
2 Basso, Calvo-Gonzalez and Jurgilas (2007), for example, examine aggregate data across 24 countries for the period 2000-2006 and find that access to international funding, exchange rate volatility and domestic inflation affect loan dollarization. Interest rate differentials seem less important. Rosenberg and Tirpak (2008) confirm that international funding is a key determinant of loan dollarization, while Luca and Petrova (2008) suggest that domestic deposits in foreign currency are also an important driver. However, these supply side explanations of foreign currency borrowing are questioned by Haiss, Paulhart and Rainer (2008) who find that foreign bank entry does not explain loan dollarization in 16 transition countries.
} 
businesses. Very little is known about the attraction and characteristics of borrowing in low-yielding currencies by this key segment of the economy.

A number of recent theoretical papers have started to model the choice of loan currency in a way that may also be relevant for small firms (Allayannis, Brown and Klapper (2003)). Cowan (2006), for example, predicts that firms with more foreign income and firms in countries with a higher interest differential will have more foreign debt, but the match between income streams and denomination of debt is naturally tighter for more firms that could face higher distress costs in the event of default.

We introduce an information asymmetry between banks and firms in a framework that also features a trade-off between the cost and risk of debt. We conjecture that banks do not necessarily know the currency in which firms have contracted their sales, and/or the firms' actual revenue levels. Information asymmetries between banks and firms underpin our modern understanding of financial intermediation (Freixas and Rochet (2008)). Information asymmetries concerning currency and revenues may be aggravated in developing and transition countries. Corporate law is weak in these countries, and it may be hard for banks to assess the credibility of available firm-level financial information. Firms can therefore often borrow without having any audited statements. Banks also can not verify firm sales information through advanced cash management services, which are yet to be introduced in many firms. Consequently, "soft" information may be the only type of information that is available, but foreign banks - which are widely present in developing and transition countries - may struggle to collect and use it (Stein (2002), Detragiache, Tressel and Gupta (2008)).

If the interest rate on foreign currency funds is lower, local currency earners with low distress costs vis-à-vis the interest rate will differentially choose foreign currency loans. Our 
model shows that if the banks are imperfectly informed about the currency in which the firms earn, then more local earners switch to foreign currency loans, as the firms do not bear the full cost of the corresponding default risk.

We test these implications of our theoretical model by investigating the currency denomination of individual bank loans granted to small firms. We use a 2005 survey of 9,655 firms from 26 transition countries, which yields 3,105 actual bank loan observations in an synthetic panel running from January 2002:I to 2005:II. At the firm level, we find that small businesses that have foreign currency income or assets are more likely to borrow in foreign currency. In contrast, we find hardly any evidence that firm-level distress costs or financial transparency affect the decision to borrow in foreign versus local currency. At the country level, we find that interest rate differentials and exchange rate movements do not explain the differences in foreign currency borrowing. Instead, we find that foreign bank presence, weak corporate governance and the regulations on incoming international capital flows do help explain the large cross-country variation in foreign currency borrowing within our sample.

In sum, while we do find some evidence for the trade-off between debt risk and cost having an influence on loan currency denomination, we cannot confirm that information asymmetries at the firm level and currency speculation are key driving forces of the recently observed increase in the dollarization of small business loans in Eastern European transition countries. Our findings on the proxies for country-level asymmetries, however, suggest that transparency-enhancing policy innovations can reduce foreign currency borrowing.

The rest of the paper is organized as follows. Section II discusses the theoretical and empirical literature. Section III introduces the main hypotheses, ingredients and specifics of 
our theoretical model. Section IV describes the data and the empirical model, while Section V discusses the firm- and country-specific empirical results. Section VI concludes.

\section{Literature}

\section{A. Theory}

A number of recent papers model the choice of the loan currency denomination by firms borrowing from financial institutions or investors (see Allayannis, Brown and Klapper (2003) for example for a pointed review). Managing the risk from economic exposure clearly matters in this choice: if the firm's cash flows are in foreign currency, borrowing in the same foreign currency will provide a straightforward natural hedge (Goswami and Shrikhande (2001)). ${ }^{3}$

Firms may opt for the lowest cost debt, as static capital structure trade-off theory suggests. The interest rate differential, i.e., the deviations from the uncovered interest rate parity, is then the second main determinant of the firm's choice of loan currency denomination (Graham and Harvey (2001)). ${ }^{4}$

These two elements, i.e., the management of currency risk and the cost of debt, can be traded off as in Cowan (2006). His model predicts that firms with more foreign income and firms in countries with a higher interest differential (where foreign currency funds are cheaper) will have more foreign debt. His model further shows that firms that are more

\footnotetext{
${ }^{3}$ Mian (1996), Bodnar, Hayt and Marston (1998), Brown (2001) and Allayannis and Ofek (2001), among others, analyze the hedging of foreign currency exposure, using forward contracts and derivatives for example.

${ }^{4}$ Our theoretical framework and accompanying empirical analysis will focus on small firms in emerging economies. Consequently, we do not discuss: (1) International taxation issues such as tax loss carry forwards and limitations on foreign tax credits; (2) The possibilities for international income shifting; (3) The differential costs across countries of derivatives to create synthetic local debt; and (4) Clientele effects in issuing public bonds. These issues are clearly important when analyzing the debt structure of large corporations.
} 
financially constrained (firms that experience a higher risk premium when borrowing from a bank) are more likely to match the denomination of debt to their income streams. These firms would have to borrow at higher costs if they become financially distressed due to the accumulated currency mismatches. If a bank knows a firm is mismatched, it may pass on the corresponding expected default costs immediately.

The framework in Cowan (2006) is also relevant for small firms. Small firms that have earnings in foreign currencies can be expected to borrow in these foreign currencies. Very small and highly leveraged firms, on the other hand, may have less foreign currency debt because they have a higher risk of financial distress. Our own theoretical model features not only the trade-off between the risk and the cost of debt, present in Cowan (2006), but introduces a very specific but relevant information asymmetry between banks and firms. We conjecture that the banks do not know the currency in which the firms have contracted their sales. We motivate this conjecture further when we discuss our model.

The information asymmetry for the financiers in Jeanne (2000) concerns the effort level of the exporting entrepreneurs. Exporters borrow locally in domestic or foreign currency. But borrowing in a foreign currency serves as a commitment device: The entrepreneurs have a stronger incentive for effort if they have foreign currency debt, because failure to achieve high returns is automatically sanctioned by termination. Consequently, lenders may require lower interest rates on foreign currency loans, and entrepreneurs may choose to borrow in foreign currency at equilibrium if the expected cost of early termination is more than offset by the lower interest rate that they obtain on foreign currency debt.

In contrast to Jeanne (2000), in which firms have only foreign revenues, in our model firms have domestic or foreign currency earnings. In Jeanne (2000) entrepreneurial effort is 
unobservable to the financiers; in our model, the currency in which sales are contracted and sales revenues are collected cannot be observed by the bank. Finally, Jeanne (2000) focuses on the macro policy choices, ${ }^{5}$ while our model focuses on firm decisions (which we can test, as we have access to firm-level data).

\section{B. Empirical Work}

A number of studies analyze the currency denomination of debt of large corporations within a single country. Kedia and Mozumdar (2003) for example study large US corporations. These firms, according to their results, match loan to sales currencies. But they find no evidence that tax arbitrage, market liquidity, or legal regime affects the currency choice of these corporations. Keloharju and Niskanen (2001) study 44 large Finnish corporations and document not only currency matching, but also evidence of carry trade (i.e. borrowing in the low-interest rate currency). Large Chilean and Mexican corporations, for example, also engage in currency-matching (Benavente, Johnson and Morande (2003), Cowan, Hansen and Herrera (2005), Gelos (2003)). Clark and Judge (2007) critically review these and other studies.

Not many studies have had access to the firm-level panel (country, time) data that is essential to investigate the link between loan currency denomination and firm

\footnotetext{
${ }^{5}$ Domestic currency debt allows the policymaker in the model to insure the productive sector against bad shocks. If returns are low, the policymaker avoids terminations by setting the exchange rate at the lowest possible level. Macro explanations for corporate foreign currency debt seem less relevant for our sample: (1) The domestic financial markets in the local currency may be underdeveloped in liquidity (Caballero and Krishnamurthy (2003)) and offer only short maturity debt. The small firms in our sample, however, borrow mostly from banks. Bank loans typically have a short maturity (Berger, Espinosa-Vega, Frame and Miller (2005), Ortiz-Molina and Penas (2008)). (2) Government may give free insurance to foreign currency borrowers through the fixed exchange rate regime or bail out. Foreign firm debt may even act as a disciplining device for local government as borrowers in foreign currency will be worse off after devaluation. Firms may not take into account this externality (Calvo (2001), Tirole (2003)), and our sample countries mostly have flexible exchange rate regimes. (3) Lenders may refuse to lend in the local currency, as they fear that devaluation by local government will decrease the value of their sovereign debt (the "original sin").
} 
characteristics, controlling for macro and institutional variables. A study by Allayannis, Brown and Klapper (2003) is an exception. Following Rajan and Zingales (1995) and Booth, Aivazian, Demirgüç-Kunt and Maksimovic (2001), Allayannis, Brown and Klapper (2003) investigate the capital structure of 327 of the largest East-Asian corporations, including foreign, local, and synthetic local (hedged) debt. They find that the ability to manage currency risk with risk management tools and the interest rate differentials, as well as the asset type, explain the use of foreign currency debt. A paper by Cowan (2006) investigating around 500 corporations in half a dozen Latin American countries arrives at similar findings (see also for example Esho, Sharpe and Webster (2007)). Finally, recent work by Kamil (2008) - using a new database with annual accounting information for over 2,200 non-financial companies in seven Latin American countries - investigates the effect of various exchange rate regimes on firms' incentives to hedge currency risk (see also Kamil and Sutton (2008)).

Complementing these empirical studies, we investigate the currency denomination of recent individual bank loans granted to small firms, rather than the currency denomination of the outstanding corporate debt of large corporations. Informational asymmetries may play a more important role in small firms. Motivated by our theoretical framework, we focus on the interplay between firm-specific measures of firm distress costs and informational asymmetries.

The dataset comprises survey data on 9,655 firms from 26 transition countries. While the transition in these countries may be interesting to study in its own right, what is more important for our purposes is that banks, small firms and the informational asymmetries between them play a key role in transition countries. In addition, the bank loans detailed in the dataset were granted during a period in which large changes in interest rate differentials, 
institutional arrangements and banking sector characteristics (e.g., foreign ownership) took place across the countries that are covered. Consequently, this dataset is well suited to studying the decisions made by firms about the currency denomination of their bank loans, based on a theoretical framework that highlights firm distress costs and informational asymmetries. We develop this framework in the next section.

\section{Theory}

\section{A. Introduction}

Existing models demonstrate that firms' choice of loan denomination is affected by the structure of firm revenues, interest rate differentials between local and foreign currency funds, and the distress costs of firms facing potential default (see Jeanne (2000), Allayannis, Brown and Klapper (2003), and Cowan (2006) for example). Missing in the theoretical literature so far is a model of the likely interplay between distress costs and bank-firm informational asymmetries.

We construct a simple model that clarifies how the choice of loan currency is determined by a firm's distress costs and the bank's lack of information about the firm's revenues. Our model shows that if there is an interest rate differential in favor of foreign currency funds, all foreign currency earners will prefer foreign currency loans. In addition, all local currency earners with low distress costs and high revenues will also choose foreign currency loans. In contrast, local currency earning firms with high distress costs and low revenues will prefer local currency loans. If banks cannot identify either the currency or the level of the revenues of the firm, i.e. the "firm type", then more local earners will borrow in foreign currency. Consequently, our model identifies the information asymmetry between 
lending banks and borrowing firms as a so far overlooked potential driver of "dollarization" in the credit markets.

\section{B. Assumptions}

Define $e_{t}$, the exchange rate at time $t$, to equal the amount of local currency per unit of foreign currency, normalized at $t=0$ to $e_{0}=1$. At $t=1$, the local currency either appreciates to $e_{A}<1$, with probability $p$, or it depreciates to $e_{D}>1$, with probability $1-p$. We assume that $p e_{A}+(1-p) e_{D}=1$, so that the expected exchange rate at $t=1$ equals $e_{1}^{*}=1$ and the expected depreciation of the local currency is $\Delta e=\frac{e_{1}^{*}-e_{0}}{e_{0}}=0 .^{6}$

A firm needs to invest $I=1$ in local currency at $t=0$ to receive any revenues at $t=1$. Firms differ in their revenue structure. There are three types of firms, foreign $(F)$, good local ( $L G)$ and bad local ( $L B$ ) currency earners. Foreign currency earners have revenue $R^{F}$ in foreign currency, which equals the expected revenue in local currency as the expected exchange rate equals one $\left(e_{1}^{*}=1\right.$, hence $\left.R^{F} e_{1}^{*}=R^{F}\right)$. The other two types of firms have local currency earnings. The good local currency earners have high earnings $R^{L G}$ in local currency, while the bad local currency earners have low earnings in local currency, $R^{L B}<R^{L G}$. We abstract from the possibility that foreign currency earners may differ in their income levels, as it does not alter the main insights of our model. ${ }^{7}$

\footnotetext{
${ }^{6}$ As we assume that the level of firm revenues does not change with the exchange rate, the changes in the exchange rate in our model are assumed to be real.

${ }^{7}$ Under perfect information, all foreign currency earners would take foreign currency loans at the same interest rate independent of their revenue level. With asymmetric information about firm revenues, this result also holds under reasonable assumptions on firm-level distress costs (see Brown, Ongena and Yesin (2008)).
} 
Let all firm types be physically located in the domestic country. Their owners will spend their profits locally, so firms care about their expected payoff in local currency. Firms maximize their expected income and have no other wealth (and are thus limited liable). ${ }^{8}$

Banks set prices simultaneously. When they can identify firm type, they charge a net interest rate $r_{k}^{j}$ on a loan in foreign or local currency $k, k \in\{f ; l\}$, to a firm of type $j \in\{F ; L B ; L G\}$. Banks have no capacity limits on foreign or local currency funds. We normalize the cost of foreign currency funds to $i_{f}=0$ and set the unit cost of local currency funds to $i_{l}$. We assume that the uncovered interest parity condition (UIP) is not fulfilled, and that there is an interest rate advantage to foreign currency funding for the bank, i.e. $i_{l}>i_{f}+\Delta e=0$. Extensive empirical research, using a variety of methods, has found finds that the uncovered interest rate parity condition rarely holds. ${ }^{9}$

Interest payments are made upfront at $t=0$, and the loan repayment is made at $t=1 .{ }^{10}$ Firms' earnings are verifiable ex post, so that payments are enforceable if a firm has sufficient earnings.

We assume that the exchange rate volatility is such that bad local currency earners will always default if they take a loan in foreign currency and the local currency depreciates, i.e. $R^{L B}<e_{D} \cdot{ }^{11}$ We also assume that all good local currency earners have high enough

\footnotetext{
${ }^{8}$ While we assume that firms maximize expected income, their payoff is not linear in expected income when we assume distress costs. The assumption of distress costs implies that firms care about income variance, as would be the case if we assumed firms were risk-averse.

${ }^{9}$ For surveys of this literature, see Hodrick (1987), Froot and Thaler (1990), Lewis (1995), Engel (1996), and Isard (2006).

${ }^{10}$ Given our focus, we do not derive the optimality of this debt contract (see Townsend (1979) for example).

${ }^{11}$ It is not uncommon for small firms to default on loans in foreign currency following a deep depreciation of the local currency, for example in developing countries (Ziaul Hoque (2003)). Small firms and firms in developing countries rarely use derivatives to hedge their net currency exposure (Briggs (2004), Børsum and Ødegaard (2005), and O'Connell (2005), among others).
} 
revenues that they will always be able to pay back their loan regardless of the exchange rate movements, i.e. $R^{L G}>e_{D}$. Moreover, we assume that foreign currency earners have revenues that will enable them to fully repay a local currency loan even if the local currency appreciates, i.e., $R^{F}>\frac{1}{e_{A}}$.

If firms default on a loan, they face costs of financial distress. For example, defaulters can henceforth find external financing only at penalty costs, as in Cowan (2006). In this case, the distress costs $C$ may be proportional to or convex in the default amount (though still homogenous across firms). Alternatively, these costs may involve the private value to its owner of a firm that is lost in bankruptcy (for example, in the case of small and familyowned firms (Froot, Scharfstein and Stein (1993))). ${ }^{12}$ In this case, $C$ will be independent of the default amount, but will be heterogeneous among firms. Given that our empirical analysis focuses on small and predominantly family-owned firms, we assume that distress costs (in local currency units) are constant per firm but distributed uniformly on the range $C_{i} \in[C, \bar{C}]$ for all firms $i$ of type $j \in\{F ; L B ; L G\}$.

Given the above assumptions, the payoff $v_{k}^{j}$ in local currency to a firm of type $j$ taking a loan of type $k$ equals

$$
\text { [1] } \quad v_{k}^{j}=\left\{\begin{array}{ll}
R^{j}-\left(1+r_{k}^{j}\right) & \text { if } j \in\{F ; L G\} \text { or }(j, k)=(L B, l) \\
p\left[R^{L B}-e_{A}\right]-(1-p) C_{i}-r_{f}^{L B} & \text { if }(j, k)=(L B, f)
\end{array}\right. \text {. }
$$

\footnotetext{
${ }^{12}$ Corresponding to the risk aversion of managers, as in Stulz (1984), or of firms, as in Conesa (1997) and Calvo (2001), for example.
} 


\section{Perfect Information}

We first analyze bank and firm behavior when banks are perfectly informed about the type of each firm. Under this assumption, each bank sets six interest rates. For each of the three firm types $j \in\{L G ; L B ; F\}$, they set two interest rates, depending on whether a foreign or local currency loan is offered.

The expected profits of banks in local currency from each loan type are

[2] $\quad \Pi_{k}^{j}=\left\{\begin{array}{ll}r_{k}^{j}-i_{k} & \text { if } j \in\{F ; L G\} \text { or }(j, k)=(L B ; l) \\ p e_{A}+(1-p) R^{L B}-\left(1+i_{f}\right)+r_{f}^{L B} & \text { if }(j, k)=(L B ; f)\end{array}\right.$.

Assuming perfect price competition, the expected profit on each loan type will be zero. Given our assumption that $i_{f}=0$, this leads to the following equilibrium interest rates:

[3] $r_{k}^{j}=\left\{\begin{array}{ll}i_{l} & \text { if } j \in\{F ; L G ; L B\} \text { and } k=l \\ 0 & \text { if } j \in\{F ; L G\} \text { and } k=f \\ (1-p)\left(e_{D}-R^{L B}\right) & \text { if }(j, k)=(L B, f)\end{array}\right.$.

The equilibrium interest rates displayed in [3] are straightforward to interpret: banks will charge firms for their funding costs. In addition, if a bad local currency earner takes a loan in foreign currency, the bank charges that bad firm for the expected credit risk due to the potential exchange rate movements.

Inserting the equilibrium interest rates from [3] into [1], we obtain the following results: foreign currency earners ( $F$ types) always choose foreign currency loans. They do so because there is an interest rate advantage to foreign currency loans and they do not run the risk of incurring distress costs when taking such a loan. For the same reason, all good local currency earning firms ( $L G$ types) also choose foreign currency loans. In contrast, 
bad local currency earning firms ( $L B$ types) face a trade-off: if they choose a foreign currency loan they benefit from an interest rate advantage, but they may incur distress costs if the exchange rate depreciates. The condition for LB firms to choose a local currency loan is

[4] $\quad(1-p) C_{i} \geq i_{l}$.

From condition [4], we can derive that the marginal $L B$ firm that will choose a local currency loan is the one with distress costs equal to

$$
C_{\text {perfect info }}^{L B}=\frac{i_{l}}{1-p}
$$

All $L B$ firms with lower distress costs will choose foreign currency loans. We assumed that the distress costs are distributed uniformly on $C_{i} \in[C, \bar{C}]$. As a result we obtain the equilibrium share of $L B$ firms that choose foreign currency loans as

$$
\text { [6] } \delta_{\text {perfect info }}^{L B}=\left\{\begin{array}{ccc}
0 & \text { if } & \frac{i_{l}}{1-p}<\underline{C} \\
\frac{i_{l}}{\frac{1-p}{\bar{C}-\underline{C}}} & \text { if } & \underline{C} \leq \frac{i_{l}}{1-p} \leq \bar{C} \\
1 & \text { if } & \frac{i_{l}}{1-p}>\bar{C}
\end{array}\right.
$$

To summarize, if there is an interest rate differential in favor of foreign currency funds, under perfect information all foreign currency earners will prefer foreign currency loans. In addition, all local currency earners with low distress costs or high revenues also choose foreign currency loans. Only local currency earning firms with high distress costs and low revenues choose local currency loans. 


\section{Imperfect Information}

We now introduce an information asymmetry between banks and firms about the revenues of the firms. Our model allows for two dimensions of information asymmetry. First, banks may not be able to verify the currency denomination of firm revenues, i.e., banks may not be able to distinguish $F$ firms from the joint pool of $L G$ and $L B$ firms. A lack of information about the currencies that are employed by the firms may correspond to the real situation for many banks, especially in transition / developing countries and for small firms. In general, the currency denomination of a firm's current and future sales contracts is often negotiated, ${ }^{13}$ and consequently may be a closely guarded secret. Second, banks may not be able to verify the level of revenues of local currency earners, i.e., to distinguish $L G$ from $L B$ firms. This corresponds to the commonly made assumption in small enterprise finance that it is difficult for banks to distinguish good from bad firms. In both cases, banks may have difficulties or lack incentives to collect detailed information about firm revenues, depending on bank type, size or ownership and the degree of competition in the banking sector. These costs of information acquisition are also particularly high when dealing with small firms, which are less likely to have audited financial accounts (Berger and Udell (1998)). ${ }^{14}$

\footnotetext{
${ }^{13}$ See Friberg and Wilander (2008) for example. This may be a consequence of firm risk aversion (Viaene and de Vries (1992)). Currency variability (Engel (2006) among others) and medium of exchange considerations (Rey (2001)) may also determine currency choice.

${ }^{14}$ Banks may lack information on firm quality, project choice, or managerial effort, for example, incurring monitoring costs (Diamond (1984), Diamond (1991)) or forming relationships with the firms (Sharpe (1990), Rajan (1992), von Thadden (2004), Hauswald and Marquez (2006), Egli, Ongena and Smith (2006), or Black (2006), among others). Foreign banks may be less informed about the activities of local firms (Rueda Maurer (2008), Detragiache, Tressel and Gupta (2008), Giannetti and Ongena (2008) and Giannetti and Ongena (2008)), while intense competition between banks may make relationship banking more or less beneficial (Petersen and Rajan (1995), Boot and Thakor (2000), Elsas (2005) and Degryse and Ongena (2007)).
} 
Information asymmetries concerning both currency and level of revenues are aggravated in developing and transition countries, where due to the weak corporate legal system, it is hard for banks to assess the credibility of available firm-level financial information (Pistor, Raiser and Gelfer (2000), Brown, Jappelli and Pagano (2008)). As a result, firms in developing and transition countries often borrow without having any audited statements (e.g., Dollar and Hallward-Driemeier (2000)), and banks cannot verify firm sales information through advanced cash management services, for example. Indeed, advanced cash management services are yet to be introduced in many of these countries, either because banks do not offer (e.g., Tsamenyi and Skliarova (2005)) or firms do not demand them (for example, in the survey we analyze, one third of the firms report receiving less than one third of their income through their banks). Hence, "soft" information may be the only type of information that is available. But the large and foreign banks that are widely present in developing and transition countries may have problems collecting and using soft information (Stein (2002), Detragiache, Tressel and Gupta (2008)).

We therefore assume in the following that banks can neither verify the currency denomination nor the level of revenues of a firm, i.e., banks cannot distinguish $F$ from $L G$ from $L B$ type firms. We assume that banks know that some given proportion $\lambda \in[0,1]$ of the total firm population are $L B$ firms, and that the remaining proportion $1-\lambda$ are either $F$ or $L G$ firms. The bank does not need to separate $F$ from $L G$ firms, as from the previous section we know that these two types never default on any loan, and thus should both receive the same (risk-free) interest rate on either a local or foreign currency loan.

We assume that all banks are equally affected by the information asymmetry, regardless of the currency in which they lend. This assumption corresponds to the situation in the financial sector in Eastern Europe, for example, where most domestic and foreign 
banks are observed to offer loans in both local and foreign currency to local firms. The assumption centers our model on the variation in firm type, simplifying the interpretation of its findings.

In contrast, in international renditions of the pecking order hypothesis, ${ }^{15}$ or in models with costly monitoring and an agency cost of debt, ${ }^{16}$ local and foreign financiers are different, for example in terms of monitoring cost or level of scrutiny, and are likely to lend only in their own currency. However it is not clear that these international extensions of pecking order or monitoring models, whereby banks lend only or primarily in their own currency, apply unequivocally to most small firms in many countries. Indeed, the small firms in our sample borrow locally in local and foreign currencies from both domestically and foreign-owned banks.

Recall that under perfect information, all $F$ and $L G$ firms take foreign currency loans and are charged a zero interest rate. In contrast, among $L B$ firms, only those firms with low distress costs take foreign currency loans, and these firms are charged a non-zero interest rate due to their positive default risk. We now show that under imperfect information, $L B$ firms do not bear the full costs of their default risk and thus are more inclined to take foreign currency loans.

With imperfect information concerning the currency and level of revenues, banks can no longer condition their interest rates on firm types. Banks thus only offer two rates: $r_{l}$ for

\footnotetext{
${ }^{15}$ Under the pecking order hypothesis, local financiers have better information about the firm than foreign financiers. If all financiers lend only in their own currency, firms will borrow first in the local and then in the foreign currency, after having exhausted internal funds.

${ }^{16}$ Firms with high monitoring costs, in Diamond (1984), for example, should borrow more locally in the local currency. If borrowing abroad, in the foreign currency, entails more regulatory scrutiny, hence distress costs, better firms in Ross (1977) will borrow in the foreign currency to signal their quality. In Jeanne (1999) and Besancenot and Vranceanu (2004) foreign debt is more expensive and firms signal that they are not fragile by engaging in 'excessive' borrowing in the foreign currency. In Titman and Trueman (1986), foreign lenders are of a higher quality.
} 
local currency loans and $r_{f}$ for foreign currency loans. In this case, the expected profits of banks in local currency from the two loan types are

$$
\text { [7] } \Pi_{k}=\left\{\begin{array}{ll}
r_{l}-i_{l} & \text { if } k=l \\
\frac{\delta \lambda\left[p e_{A}+(1-p) R^{L B}\right]+(1-\lambda)}{\delta \lambda+(1-\lambda)}-\left(1+i_{f}\right)+r_{f} & \text { if } k=f
\end{array},\right.
$$

where $\delta \in[0,1]$ is the equilibrium share of $L B$ firms taking foreign currency loans. In equilibrium, and with zero expected profit, interest rates must equal:

[8] $r_{k}=\left\{\begin{array}{ll}i_{l} & \text { if } k=l \\ \frac{\delta \lambda}{\delta \lambda+(1-\lambda)}(1-p)\left(e_{D}-R^{L B}\right)>0 & \text { if } k=f\end{array}\right.$.

The interest rate charged on foreign currency loans covers the expected losses due to default on such loans. Under imperfect information, this depends on the share of $L B$ firms taking such loans relative to $F$ and $L G$ firms. Note that the interest rate that lenders charge on foreign currency loans lies between the rates it charges for such loans under perfect information to $F$ and $L G$ firms, i.e. 0 , and $L B$ firms, i.e. $r_{f} \in\left[0, r_{f}^{L B}\right]$.

Note that in [7] and [8] we assume that in equilibrium all $F$ and $L G$ firms take foreign currency loans under imperfect information. From [1] we know that this will be the case as long as the equilibrium interest rate on foreign currency loans is lower than that on local currency loans, i.e. $r_{f}<r_{l}$. At the end of this section, we discuss the conditions under which this is the case.

Bad local currency earners for which $v_{f}^{L B}\left(r_{f}, C_{i}\right) \geq v_{l}^{L B}\left(i_{l}, C_{i}\right)$ will choose foreign currency loans. From [1] and [8] we see that this will be the case for all $L B$ firms with distress costs not higher than: 


$$
C_{\text {imperfect info }}^{L B}=\frac{i_{l}}{1-p}+\frac{(1-\lambda)}{\delta \lambda+(1-\lambda)}\left(e_{D}-R^{L B}\right),
$$

where the share of bad local currency earning firms taking foreign currency loans is determined in equilibrium by $\delta_{\text {imperfect info }}^{L B}=\frac{C_{\text {imperfect info }}^{L B}-\underline{C}}{\bar{C}-\underline{C}}$. Note that $C_{\text {imperfect info }}^{L B}>C_{\text {perfect info }}^{L B}$.

From [9], we can establish that the lowest interest rate $i_{l}$ at which $L B$ firms opt for foreign currency loans is $i_{l}=(1-p)\left(\underline{C}+R^{L B}-e_{D}\right)$. We assume from now on that

$$
\underline{C} \geq e_{D}-R^{L B}>0
$$

This assumption ensures that unless there is a positive interest rate differential to the advantage of foreign currency funds, all $L B$ firms will choose local currency loans. This assumption negates the possibility that some $L B$ firms choose foreign currency loans due to their limited liability even in the absence of an interest rate differential. We can further establish from [9] that for all interest rate levels $i_{l} \geq(1-p)\left[\bar{C}-(1-\lambda)\left(e_{D}-R^{L B}\right)\right]$, all $L B$ firms will choose foreign currency loans. For interest rate levels in the range $(1-p)\left(\underline{C}+R^{L B}-e_{D}\right)<i_{l}<(1-p)\left[\bar{C}-(1-\lambda)\left(e_{D}-R^{L B}\right)\right]$, a certain proportion $0<\delta<1$ of $L B$ firms will choose foreign currency loans under imperfect information.

We now establish that for each interest rate level in this range, there is a unique marginal firm that takes a foreign currency loan, and that this firm is characterized by higher distress costs under imperfect information than under perfect information: $C_{\text {imperfect info }}^{L B}>\frac{i_{l}}{1-p}=C_{\text {perfect info }}^{L B}$.

As the left hand side of [9] is increasing and continuous in $C_{\text {imperfect info }}^{L B}$ and the right hand side is decreasing and continuous in $C_{\text {imperfect info }}^{L B}$, there is at most one level of 
$C_{\text {imperfect info }}^{L B}$ for which condition [9] can be met. Note further that at $C_{\text {imperfect info }}^{L B}=\frac{i_{l}}{1-p}$, the left hand side is less than the right hand side. As a consequence, a unique equilibrium exists, $C_{\text {imperfect info }}^{L B}>\frac{i_{l}}{1-p}=C_{\text {perfect info }}^{L B}$, if for $C_{\text {imperfect info }}^{L B}=\bar{C}$ (and $\delta=1$ ) the right hand side of the condition is smaller than the left hand side. This is the case for all $i_{l}<(1-p)\left[\bar{C}-(1-\lambda)\left(e_{D}-R^{L B}\right)\right]$, and thus for the range of interest rates under consideration.

We can now characterize the share of $L B$ firms that take foreign currency loans under imperfect information as follows:

$$
\delta_{\text {imperfect info }}^{L B}\left\{\begin{array}{lll}
=0 & \text { if } & i_{l} \leq(1-p)\left(\underline{C}+R^{L B}-e_{D}\right) \\
>\delta_{\text {perfect infoo }}^{L B} & \text { if } & (1-p)\left(\underline{C}+R^{L B}-e_{D}\right)<i_{l}<(1-p)\left[\bar{C}-(1-\lambda)\left(e_{D}-R^{L B}\right)\right] . \\
=1 & \text { if } & i_{l} \geq(1-p)\left[\bar{C}-(1-\lambda)\left(e_{D}-R^{L B}\right)\right]
\end{array}\right.
$$

Comparing conditions [11] and [6] we can conclude that more local currency earners will choose foreign currency loans under imperfect information than under perfect information.

We have assumed throughout this section that all $F$ and $L G$ firms choose foreign currency loans in equilibrium. From [1], we know that this will be the case as long as the equilibrium interest rate on local currency loans is higher than that on foreign currency loans. From [8] we see that this will be the case as long as the interest rate differential to the advantage of foreign currency funds is

$$
i_{l} \geq(1-p)\left(e_{D}-R^{L B}\right)
$$

Due to our assumption in [10], this condition is met in any equilibrium under imperfect information where $L B$ firms choose foreign currency loans. 


\section{E. Empirical Predictions}

\section{Firm Level}

Our model above yields several testable hypotheses regarding firm-level choice of loan denomination. We predict that the likelihood of choosing a foreign currency loan is positively related to the share of income a firm earns in foreign currency. Under the assumptions of our model, all foreign currency earners choose foreign currency loans, so the proportion of foreign currency earners taking foreign currency loans is always at least as high as that of local currency earners.

However, our model shows that not only the currency denomination of a firm's cash flow is important, but also the magnitude of its cash flows compared to its potential loan repayments. Among firms with local currency earnings, firms with large revenues compared to their credit obligations are more likely to take foreign currency loans.

As predicted by existing models (Jeanne (2000), Allayannis, Brown and Klapper (2003), and Cowan (2006) for example), the choice of a foreign currency loan should further be negatively related to the firm-level distress costs. The impact of distress costs on loan denomination should be stronger the lower the share of income a firm receives in foreign currency and the lower the revenue.

A key prediction of our model is that the choice of a foreign currency loan by local currency earners should be positively related to the opaqueness of the firm's revenue structure. More local currency earners choose foreign currency loans under imperfect information than under perfect information. The impact of information opaqueness is stronger for firms with higher shares of revenue in local currency (our model suggests that imperfect information does not alter the currency choice for firms with foreign currency earnings only). 


\section{Country Level}

At the macroeconomic level, our model predicts that the choice of a foreign currency loan will be positively related to the interest rate advantage on foreign currency funds. The impact of the interest rate differential, however, does depend on firm characteristics. The reaction to an increase in the interest rate differential should be stronger for firms with less income in foreign currency.

The choice of a foreign currency loan will further be negatively related to exchange rate volatility. If the local currency is more likely to depreciate, local currency earners (with low revenues) will be less likely to take a foreign currency loan. Moreover the impact of exchange rate volatility should be stronger for those firms with higher distress costs.

Finally, our model suggests that characteristics of the banking sector or of the legal environment that exacerbate information asymmetries between banks and firms may foster unhedged foreign currency borrowing. The following is a summary of the model predictions: 


\begin{tabular}{|c|c|}
\hline \multicolumn{2}{|c|}{$\begin{array}{l}\text { Effect of determinants of the choice of a foreign currency loan } \\
(+) \text { : positive effect, }(-) \text { : negative effect) }\end{array}$} \\
\hline Firm level determinants & \\
\hline$\%$ Income in foreign currency & $(+)$ \\
\hline Distress costs & $(-)$ \\
\hline$\%$ Income in foreign currency $*$ Distress costs & $(+)$ \\
\hline Opaqueness of revenues & $(+)$ \\
\hline$\%$ Income in foreign currency $*$ Opaqueness of revenues & $(-)$ \\
\hline Country level determinants & \\
\hline Interest rate differential (local minus foreign) & $(+)$ \\
\hline$\%$ Income in foreign currency $*$ Interest rate differential & $(-)$ \\
\hline Exchange rate volatility & $(-)$ \\
\hline Distress costs $*$ Exchange rate volatility & $(-)$ \\
\hline Banking sector or legal impediments to transparency & $(+)$ \\
\hline
\end{tabular}

\section{Data}

Firm-level loan information was obtained from the Business Environment and Enterprise Performance Survey (BEEPS). The European Bank for Reconstruction and Development (EBRD) and the World Bank jointly conducted this survey in 1999, 2002 and 2005. Our analysis is based on the 2005 version, as it contains the most comprehensive information on the borrowing behavior of the firms.

First, we relate this information to firm-level indicators of revenue sources, distress costs and opaqueness taken from the same survey. Then we relate our firm-level loan information to country-level indicators of macroeconomic conditions, as well as characteristics of the banking sector and institutional environment, taken from the 
International Financial Statistics (IFS) and Annual Reports on Exchange Rate

Arrangements and Exchange Rate Restrictions (AREAER) compiled by the International Monetary Fund (IMF), the Transition Report published by the EBRD, and Basso, CalvoGonzalez and Jurgilas (2007). The definitions and data sources for all variables used in our empirical analysis are presented in Table 1.

[Table 1 here]

\section{A. Firm-Level Borrowing Behavior}

BEEPS 2005 provides data on 9,655 firms in 26 transition countries and covers a representative sample of firms for each of these countries. ${ }^{17}$ In this sample, 4,062 firms report detailed information on their most recent loan. Most important for our analysis, the survey includes an indicator of the currency denomination of the loan. Each firm states whether its most recent loan was denominated in local or foreign currency. The answer to this question is our dependent variable Forex loan, which takes the value one if the most recent loan was denominated in a foreign currency and zero if the most recent loan was in local currency. The survey further lists the precise date the loan was received and information on collateralization, duration, and interest rate.

Table 2 provides summary statistics on the characteristics of loans in our sample by country. We exclude all observations for which the firm did not indicate the currency denomination (346 observations) and for which loans were received earlier than January 2002. ${ }^{18}$ We are left with 3,105 observations. In this sample, $25 \%$ of the loans are

\footnotetext{
${ }^{17}$ The survey covers all countries in which the EBRD is operational, with the exception of Turkmenistan. See http://www.ebrd.com/country/sector/econo/surveys/beeps.htm for detailed information on BEEPS 2005.

${ }^{18}$ Rejections of loan applications may create a selection issue that may vary across quarters. We do not have any information on loan applications, and hence have to assume the choice of currency is unaffected.
} 
denominated in foreign currency. However, the percentage of foreign currency loans varies significantly across countries, from less than $10 \%$ in the Czech Republic, the Slovak Republic, Bosnia, and Uzbekistan to more than 50\% in Albania and Georgia.

[Table 2 here]

The average loan duration in our sample is 29 months, again with considerable variation across countries. The overwhelming majority of loans in most countries are collateralized, with only four countries having collateralization rates of less than $80 \%$. In contrast, the mean ratio of the amount of collateral to loan size varies substantially across countries, from less than $100 \%$ in Slovenia and Uzbekistan to more than $200 \%$ in Bosnia. Not surprisingly for our sample of transition countries, the cost of credit is substantial: the mean (nominal) interest rate exceeds $14 \%$ per annum. Pairwise correlations displayed in Panel $\mathrm{C}$ of the table suggest that the loan currency denomination is related to other loan characteristics. Foreign currency loans have a longer average duration and, not surprisingly for the countries covered, lower interest rates than local currency loans.

\section{B. Firm-Level Determinants of Loan Currency Denomination}

We start our empirical analysis by studying the firm-level determinants of loan currency choice. In our empirical model, the dependent variable $\operatorname{Pr}\left(\right.$ ForexLoan $_{i, j, t}$ is the probability that a firm of type $i$ in country $j$ chooses a foreign currency denomination when receiving a loan at time $t$ :

[14] $\operatorname{Pr}(\text { ForexLoan })_{i, j, t}=\alpha_{j, t}+\beta 1 \cdot F_{i}+\beta 2 \cdot L_{i, j, t}+\varepsilon_{i, j, t}$.

Our theoretical model suggests that a firm's decision to take a foreign currency loan should be related to the currency denomination of its revenues, the expected distress costs if it were to default on the bank loan, and the financial transparency of its activities. Our 
empirical model therefore includes a vector of firm-level indicators $\left(F_{i}\right)$ from BEEPS 2005 that captures the corresponding firm-level characteristics. ${ }^{19}$

\section{Revenue Currency}

We use three indicators of a firm's revenue currency denomination. The dummy variable Exporter equals one if the firm exports and zero if the firm obtains revenues only from domestic sales. In countries where domestic sales are conducted exclusively in domestic currency, we believe that this dummy variable is a good indicator of whether a firm has foreign currency income or not.

However, many of the countries in our sample display a strong degree of "dollarization", i.e., many domestic transactions are also conducted in foreign currency. To take this into account, we include a firm-level indicator of the extent of domestic sales in foreign currency. The variable Sales to multinationals equals one if the firm makes domestic sales to multinational or foreign-owned companies. Such sales are more likely to be made in foreign currency.

Finally, in addition to current sales, assets in foreign currency could be an additional potential source of foreign currency cash flows. The BEEPS survey does not provide us with detailed information on the asset structure of firms. We therefore use foreign firm ownership as an indicator of whether firms have assets that yield foreign currency cash flow. The variable Foreign firm equals one if more than $50 \%$ of the firm's ownership is in

\footnotetext{
${ }^{19}$ These characteristics are taken to be those prevailing at the time of the interview (in 2005) or for the 12 months prior to the interview. For most firms, this implies that our firm-level explanatory variables are elicited after their most recent choice of loan currency. However, our theory also suggests that it is the expected firm characteristics (in particular, income currency and its verifiability, and distress costs) at the time of loan repayment - and not necessarily at the time of loan disbursement - which drive the currency choice. For a subset of 506 firms we have access to the firm-level characteristics from the 2002 BEEPS survey. We replicated our full-sample firm-level analysis using these 2002 values instead of the 2005 values We found no significant correlations between the 2002 firm characteristics and their choice of loan currency.
} 
foreign hands, and zero otherwise. Foreign-owned firms are more likely to have foreign currency loans, as they are more likely to have foreign currency income.

\section{Distress Costs}

We include three indicators of distress costs that occur when firms default on their most recent bank loan. Expected distress costs are higher for entrepreneurs deriving more private intangible value from their firm. This value may be lost if these firms default. Expecting that this private value is higher for sole proprietorships or family owned businesses, we include the variable Family firm. This dummy variable equals one if the firm is a sole proprietorship or a family owned business, and zero otherwise.

A further indicator of private intangible value is the variable Security costs, which measures the percentage of annual sales that firms pay for security-related services. We surmise that the private value of running a business may be lower in a less secure environment, and thus in an environment where security costs are higher.

Theory finally suggests that highly leveraged firms have higher distress costs, as they face higher costs of accessing additional external finance (Cowan (2006)). Our final indicator of distress costs, Debt, therefore relies on a measure of firm leverage available from BEEPS 2005, namely the share of working capital financed by debt in the 12 months prior to the interview.

\section{Opaqueness}

Our theoretical model suggests that loan denomination may further be related to the degree of opaqueness about the firms' revenue sources. If banks cannot identify the currency or level of firm revenues, our theory suggests that some local currency earners may pretend to be foreign exchange earners in order to receive cheaper foreign currency credit. As a 
result, firm opaqueness may lead to a higher probability of local currency earners taking foreign currency loans if a corresponding interest rate advantage exists. Note, however, that firm opaqueness may not lead to more foreign currency borrowing when we consider the full sample of firms. First, if in addition to firms with non-verifiable revenues there are some firms that have verifiable foreign currency earnings, then we could observe a positive relationship between foreign currency borrowing and financial transparency, as banks offer foreign currency loans to transparent firms at lower rates than to opaque firms.

Furthermore, severe information asymmetry could lead to a collapse of the foreign currency credit market for those firms with non-verifiable revenues. In this case only transparent firms with foreign currency income would receive foreign currency loans.

We include two firm-level indicators of opaqueness in our analysis. Our first indicator is based on firms' financial reporting standards. The variable Audited firm equals one for all firms with an external auditor and equals zero otherwise. Our conjecture is that firms with audited accounts are in a position to provide more credible information about their revenue sources to banks. Our second indicator of firm opaqueness, Income via bank, measures the share of the firm's sales that are settled through a bank account. We expect that the higher this share, the better banks are informed about the revenue sources of the firms ( $a$ la Mester, Nakamura and Renault (2007) and Norden and Weber (2007)).

\section{Control Variables}

In addition to our indicators of firm revenue, distress costs and opaqueness, we include three firm variables and sector fixed effects to control for any other differences in 
firm characteristics. ${ }^{20}$ The variable International accounting equals one for all firms that apply international accounting standards (IAS or US GAAP), and equals zero otherwise. Firms with stronger relations to foreign markets or investors are more likely to apply international accounting standards. At the same time, adhering to international accounting standards makes firms more transparent.

The variable Small firm equals one for firms with less than 50 employees and equals zero otherwise. Distress costs related to foreign currency borrowing may be larger for small firms, at least in proportion to loan size (Froot, Scharfstein and Stein (1993)). On the other hand, small firms may also be more opaque.

Finally, we include firm Age, measured at the time of disbursement of the most recent loan. The information about the firm's activities may become more accurate and credible as the firm grows older and can provide a longer public track record. On the other hand, because of the transition in the countries we consider, age may also proxy for export income, ownership and financial transparency.

We further include two characteristics of each loan $\left(L_{i, j, t}\right)$. The variable Duration measures the duration of the loan in months at origination, while the variable Collateralized equals one if the loan is collateralized, and zero otherwise. We assume banks determine duration and collateral prior to currency. However, dropping both loan variables does not alter our findings.

\footnotetext{
${ }^{20}$ We classify each firm into one of the following seven sectors based on where it obtains the largest percentage of its revenues: Mining; Construction; Manufacturing; Transport and communication; Wholesale, retain and repairs; Real estate; and Hotels and restaurants.
} 


\section{Summary Statistics}

Table 3 provides summary statistics for our firm-level explanatory variables (statistics for the two loan characteristics were already provided in Table 2). The table displays the full sample means for each variable, and then compares means for the firms with local / foreign currency loans. The table suggests that firms with foreign currency loans differ systematically from those with local currency loans. As expected firms with foreign currency loans are much likely to have export income, sales to multinationals, and foreign owners. Note, however, that less than half (43 percent) of the firms with foreign currency loans have export income. This finding suggests that many firms that are taking foreign currency loans may be unhedged.

[Table 3 here]

Table 3 further shows that firms with foreign currency loans make higher expenditures for security services, suggesting that their distress costs may lower. On the other hand, there seems to be little difference in levels of family ownership and external debt between local currency and foreign currency borrowers.

Our summary statistics suggest an ambiguous relation between financial transparency and currency denomination. On the one hand, firms with foreign currency loans are more likely to be audited. On the other hand, these firms have a lower share of their income flowing through bank accounts, suggesting less financial transparency. Finally, firms taking foreign currency loans are more likely to adhere to international accounting standards, but are also smaller and younger.

Panel B displays the pairwise correlations between the firm characteristics. While some of the revenue indicators are somewhat correlated, not unexpectedly, this is not the 
case for the variables Security costs and Debt. Both variables are surprisingly uncorrelated with measures of currency revenue, Family firm, and the two transparency variables.

Our theoretical model predicts that the choice of loan denomination for a given firm will differ across countries depending on the extent of the interest rate advantage of foreign currency funds and the exchange rate volatility. In addition, loan denomination may vary across countries due to differences in expectations of future macroeconomic conditions (domestic inflation volatility) as well as characteristics of the banking sector and the institutional environment (see the next section for a detailed discussion). In our analysis of firm-level determinants of loan denomination, we control for these cross-country differences by introducing country-time fixed effects $\left(\alpha_{j, t}\right)$.

\section{Country-Level Determinants of Loan Currency Denomination}

In a second empirical step, we examine the extent to which country-specific characteristics help explain the choice of loan currency in our sample. To do so we augment our empirical model with a vector of time-varying country-level variables $\left(C_{j, t}\right)$ :

$$
\operatorname{Pr}(\text { Forexloan })_{i, j, t}=\alpha_{j}+\beta 1 \cdot F_{i}+\beta 2 \cdot L_{i, j, t}+\beta 3 \cdot C_{j, t}+\varepsilon_{i, j, t} .
$$

As not all country-specific characteristics are available for all countries and all quarters, in this second step we rely on varying subsamples.

\section{Macroeconomic Determinants}

Our main country-level explanatory variable is an indicator of the interest rate differential between local currency and foreign currency funds. We use four indicators of the nominal interest rate differential. Our first two indicators are calculated using benchmark interest rates in the domestic and foreign financial sectors. We label our first measure the Interest differential - USD indicator, because we calculate it using the 
domestic Treasury bill rate (taken from IFS, line 60c), and the interest rate on US Treasury bills (IFS, line 60c), for the past quarter. ${ }^{21}$ The Interest differential - Euro indicator is similarly calculated as the domestic interest rate minus the Eurepo rate (also taken from IFS). Our two further indicators of the interest rate differential are taken from Basso, CalvoGonzalez and Jurgilas (2007). They obtain actual interest rate differentials between local currency and foreign currency, by surveying central banks in transition economies. Their survey allows them to compile monthly information on interest rate differentials on loans and deposits for 24 transition countries over the period 2000-2006. Unfortunately, their direct measures of interest rate differentials are not available for all countries throughout the whole observation period. We nevertheless use their indicators, which we label Interest differential - loans and Interest differential - deposits, where possible.

As elaborated in our theory section, foreign currency borrowing should be driven by interest rate differentials after taking into account expected changes in the exchange rate. Firms should care about departures from uncovered interest parity, which constitute a real differentials in interest rates between local currency and foreign currency funds. Unfortunately, we have no measure of expected depreciation for our sample of countries. We therefore control for expected depreciation using the realized nominal depreciation of the local currency versus the US dollar (Depreciation - USD) or euro (Depreciation Euro) during the past quarter (taken from IFS).

Our theory suggests that local currency earning firms will be less likely to take foreign currency loans when exchange rate volatility is high. We include two variables that measure the actual variance of month on month changes per currency in the real exchange rate vis-à-

\footnotetext{
${ }^{21}$ Where a Treasury bill rate was not available, we used the central bank reference rate or money market rate available from IFS.
} 
vis the US dollar (Depreciation volatility - USD) and the euro (Depreciation volatility $U S D$ ) respectively (again taken from IFS). We take the actual variance in exchange rate movements for the past 12 months prior to each quarter. In addition to our measure of actual exchange rate volatility, we include two measures of the exchange rate regime, which may affect agents' expectations. We distinguish countries with a fixed exchange rate (Peg), i.e. those with a currency board, fixed peg or crawling peg, from those with a floating exchange rate regime. Our classification of exchange rate regimes is based on the IMF's “Annual report on Exchange Arrangements and Exchange Restrictions” (AREAER). Further, affiliation with the European Union may shape expectations about future currency arrangements, as new member states are automatically on track to join the Euro-zone. We therefore distinguish those countries that have completed negotiations to join the European Union $(E U)$ from those that have not. A pegged exchange rate and expected EU accession may spur foreign currency borrowing.

In our model we ignore uncertainty about domestic inflation. In reality, however, volatility in the purchasing power of the local currency may affect borrowers' loan choice. In a model of optimal portfolio choice, Ize and Levy-Yeyati (2003), for example, show that risk-averse borrowers will choose the currency composition of their liabilities taking into account the relative volatility of domestic inflation and the real exchange rate. As we predict above, foreign currency borrowing should decrease with volatility in the exchange rate. Ize and Levy-Yeyati (2003), however, also show that foreign currency borrowing should increase with volatility of domestic inflation. We account for this by including in our models the variable Inflation volatility, which measures the variance of month on month changes in the domestic consumer price index (also taken from IFS). 


\section{Banking Sector and Institutional Variables}

Our model predicts that the ability of local currency earners to borrow in foreign currency will be affected by the information of banks on the firm's sources of revenues. This information will not only depend on the firm-level transparency, but also on bank characteristics and the institutional environment in which the bank operates. Foreign-owned banks may have less knowledge about the activities of local firms (see, Detragiache, Tressel and Gupta (2008), Giannetti and Ongena (2008) and Giannetti and Ongena (2008) for example). As a first indicator of countrywide information asymmetries, we include a variable that captures the foreign presence in the banking sector. The variable Foreign banks measures the asset share of foreign controlled banks on a yearly basis per country, and is taken from the EBRD transition report. Informational asymmetries in the banking sector may also be affected by the extent to which domestic corporate law promotes good corporate governance. We therefore include the EBRD Enterprise reform index, which measures on a yearly basis the degree to which corporate governance meets international standards in each transition country.

We expect that the probability of a firm taking a foreign currency loan should be naturally related to the degree of real "dollarization" in its country. We include two countrylevel explanatory variables that measure the degree to which the foreign currency is used in the local economy. Our first indicator is the share of banking deposits that are held in foreign currency (Forex deposits), taken from Basso, Calvo-Gonzalez and Jurgilas (2007). Our second measure of real dollarization is the dummy variable $C I S$, which equals one for all countries that are members of the Commonwealth of Independent States from the former Soviet Union. Existing aggregate evidence by Basso, Calvo-Gonzalez and Jurgilas (2007) 
and Luca and Petrova (2008) suggests that real dollarization is substantially higher in these countries in the former Soviet Union than in other Eastern European transition countries.

The demand for foreign currency loans may further be influenced by firms' access to other currency hedging instruments. While we believe that the use of currency derivatives should be limited in our sample of firms, we nevertheless include a measure of the availability of such instruments. The dummy variable Forward fx market captures whether (or not) the forward currency market is well developed in a country, and is taken from the IMF's AREAER publication.

Regulations on capital flows may limit the supply of foreign currency loans by domestic banks. Basso, Calvo-Gonzalez and Jurgilas (2007) and Luca and Petrova (2008) find that banks' access to foreign funding is strongly correlated with aggregate levels of foreign currency lending in transition countries. Controls on international borrowing or foreign direct investment may limit the access of banks to such funding. We therefore include the variable Capital controls (taken from AREAER), which measures whether there are controls on foreign borrowing by or foreign direct investment in domestic firms (including banks) in a country.

Finally, the supply of foreign currency loans by domestic banks may be affected by regulatory limits on their open foreign currency positions. To capture this, we include the variable Open fx position (also taken from AREAER), which measures the maximum total open foreign currency position a bank in a country may have as a percentage of its capital.

\section{Summary Statistics}

Table 4 displays summary statistics for our macroeconomic explanatory variables, with Panel A displaying means by country. This table reveals positive values of the interest rate differential in almost all countries independent of the indicator considered. This implies 
a widespread interest rate advantage to taking foreign currency loans rather than local currency loans in our sample. This interest rate advantage does, however, vary substantially across countries. Panel B of Table 4 further shows that there is a substantial decline in the nominal interest rate differential over time. The variables Interest rate differential - USD and Interest rate differential - Euro decline from more than $10 \%$ in 2002 to below $4 \%$ in 2005. The decline is more moderate in the two interest rate differentials obtained from Basso, Calvo-Gonzalez and Jurgilas (2007). This may be due to the fact that their panel data is unbalanced.

\section{[Table 4 here]}

Table 4 confirms that uncovered interest parity did not hold (ex-post) for the majority of countries in our sample during the observation period. Despite the substantial interest rate disadvantage vis-à-vis the US dollar, we find that the currencies of most countries appreciated (rather than depreciated) against the US dollar. Moreover, while the majority of currencies did depreciate against the euro, the magnitude of this depreciation was substantially lower than that of the nominal interest rate differential.

Table 5 summarizes the exchange rate regime and political affiliation per country for our observation period of 2002:I to 2005:II. The majority of countries have a floating exchange rate regime. Several countries with plans to join the EU, however, adhere to a fixed rate regime in line with the Exchange Rate Mechanism II program.

[Table 5 here]

Table 6 displays summary statistics for our indicators of the banking sector and institutional environment. Foreign presence in the banking sector varies strongly, with foreign banks controlling over $90 \%$ of the assets in some countries (Croatia, Estonia, Lithuania, Slovak republic), and less than $10 \%$ in others (Azerbaijan, Russia, Tajikistan, 
Uzbekistan). The table further shows that dollarization of the economy varies strongly across our sample. Half of the countries in the sample appear to be highly dollarized, with shares of foreign currency deposits in the banking sector exceeding 50\%. Panel B of Table 6 shows that dollarization dropped between 2002 and 2005, while foreign bank influence increased.

\section{[Table 6 here]}

Alternative foreign currency hedging instruments are limited in our sample, with forward currency markets underdeveloped in most countries. Furthermore, due to the existence of capital controls, banks in several countries have limited access to foreign funding. Panel B of Table 6 shows that the development of forward currency markets has only slightly improved between 2002 and 2005, while capital controls have been slightly reduced. Regulations on foreign currency positions are quite similar across countries in our sample, with open positions limited to $20 \%-30 \%$ of bank capital. The only notable exceptions are Kazakhstan and Macedonia, where banks can have open foreign currency positions up to $50 \%$ of their capital.

\section{Results}

\section{A. Firm-Level Determinants of Loan Currency Denomination}

\section{Full Sample Results}

Table 7 provides full sample estimates when Forex loan is regressed on firm and loan characteristics. Column (1) reports estimates without accounting for country fixed effects. The model in Column (2) includes country-fixed effects, Column (3) country-year effects, and Column (4) country-quarter effects. We focus on the results of Column (4), as the other models yield similar estimates but include fewer effects. We report for all regressions the 
marginal effects at the sample means based on probit estimations. The T-statistics reported in parentheses are based on standard errors clustered at the country level.

[Table 7 here]

The estimates displayed in Table 7 suggest that the choice of loan denomination is systematically related to the currency in which firms yield revenue. Exporters and Foreign firms obtain more foreign currency loans. All three coefficients are also economically relevant. At the means of the other variables, the percentage of foreign loans increases from $22 \%$ for non-exporters to $31 \%$ for exporters (remember that around $25 \%$ of all loans in the sample were in foreign currency). Similarly, the percentage of foreign loans increases from $22 \%$ for domestic to $47 \%$ for foreign firms.

Full sample estimates for our indicators of firm distress costs are mixed. As predicted we find a significant positive correlation between Security costs and loan denomination. Firms with higher security costs, which we argue have a lower private value of doing business, are more likely to take a foreign currency loan. However, this relation is not confirmed by our other two measures of distress costs (Family firm, Debt).

Estimates for indicators of firm opaqueness are also mixed. Neither Income via bank nor Audited firm display the expected significant negative coefficient, suggesting that opaqueness does not encourage foreign currency borrowing. Moreover, we find a significant positive correlation between international accounting standards and foreign currency borrowing. However, this result may be explained by the fact that firms that adhere to international standards are more likely to have foreign currency income. More in line with our prediction is the finding that firms with a longer public track record are less likely to take foreign loans. More than $27 \%$ of the loans of the new firms are in a foreign currency, while for firms of more than the mean age around $24 \%$ of loans are in the foreign 
currency. This result could indicate that in general more publicly available information about a firm decreases its ability to obtain bank loans in a foreign currency.

Finally, loans with a longer maturity are more likely to be in a foreign currency. Only $17 \%$ of the one-month loans are denominated in a foreign currency, while $26 \%$ of the threeyear loans are. The coefficient on Collateralized, on the other hand, is not significant.

\section{Sample Splits}

The fact that our full sample results are mixed for indicators of distress costs and firm opaqueness is not too surprising. After all, our theoretical framework does not predict that these indicators should affect the loan denomination choice of all firms. We expect that distress costs and opaqueness should affect loan denomination only for firms that do not have income in foreign currency. In addition, we expect that distress costs should affect firms only when exchange rates are volatile, and thus the probability of defaulting on an unhedged foreign currency loan is high. The fact that we pool firms with and without foreign currency earnings in our full sample regressions, and assume that the impact of distress costs is similar for firms in countries with stable and volatile exchange rates, may explain why the results in Table 7 are weak.

In Table 8, we try to isolate the 'true' local earners by splitting the sample according to firm-level income structure and the country-level degree of real dollarization. We first classify Non-forex firms as firms that have no export sales, no sales to multinationals, and no majority foreign owner. Forex firms are all other firms. We then classify Weakly dollarized countries as those that have a mean share of foreign exchange deposits in the banking system of $50 \%$ or less for the observation period. Table 6 shows that within our sample there are 13 such countries. Strongly dollarized economies have a mean share of foreign exchange deposits in the banking system exceeding $50 \%$ for the observation period. 
Table 6 shows that within our sample there are 12 such countries. Based on the above definitions we distinguish between Local and Foreign currency earners. Local currency earners are Non-forex firms that are situated in Weakly dollarized countries. Foreign currency earners are all other firms.

We further split our sample depending on whether firms are located in a country with a pegged or floating exchange rate. Table 5 shows that there are 15 countries with floating regimes and 12 with pegged regimes (currency board, fixed peg or crawling peg). We report the results for the corresponding subsamples in Table 8 .

[Table 8 here]

Our sample splits provide limited support the conjecture that firm-level distress costs or opaqueness affects the loan choice for Local currency earners. None of our indicators of firm distress cost (Family firm, Security costs, Debt) or opaqueness (Audited firm, Income via bank) display a significant coefficient in Column (1) of Table 8. However, comparing Columns (1) and (2) of Table 8 we do find that Audited firm displays the expected negative sign for local currency earners, while it displays a positive sign for foreign currency earners. This finding suggests that there may be a two-sided effect of financial transparency on borrowing behavior. On the one-hand, financial transparency may help foreign currency earners to borrow in foreign currency. On the other hand, as suggested by our model, financial transparency lowers the ability of local currency earners to imitate foreign currency ones. This conjecture is partly supported by our analysis in Panel B of Table 8 where we interact all firm characteristics with Local currency earner (a dummy that equals one if the firm is a local currency earner and equals zero otherwise). In Column (2) the coefficient on the interactions with Audited firm is negative and significant, providing some qualified support for the opaqueness implications of our model. 
Our sample splits provide little support for the conjecture that distress costs matter more for firms that are subject to more volatile exchange rates. In Panel A of Table 8 we find as expected that security costs affect loan choice only for firms in countries with floating exchange rates. However, the interaction effects in column (3) of Panel B suggest that the effect for security costs is not significantly different between the two sub-samples. Moreover, we find no significant results for our other two measures of distress costs, Family firm and Debt.

\section{B. Macroeconomic Determinants of Loan Currency Denomination}

\section{Full Sample Results}

In Table 9 we report a full sample analysis, including our four measures of the Interest rate differential, as well as our measures of Depreciation, exchange rate volatility (Depreciation volatility, Peg, EU), and domestic Inflation volatility. We expect the interest rate differential and inflation volatility to have positive effects, and the depreciation and exchange rate volatility to have negative effects.

\section{[Table 9 here]}

Panel A reports the coefficients for estimations excluding country fixed effects, with inference based on standard errors that are either adjusted or not adjusted for clustering at the country level. As expected, we find that the estimated coefficient is positive for all four indicators of the nominal interest rate differential. The significance of the coefficients holds for both clustered and non-clustered errors. However, while the impact of the interest rate differential is statistically significant, its economic relevance is weak. The coefficients in columns (1) and (2) of the table suggest, for example, that (at the sample mean) a $1 \%$ increase in the interest rate differential to the US dollar or euro increases the share of 
foreign currency loans by $0.6 \%$. Given the sample means of the interest rate differentials on US dollar (8.7\%) and euro (7.6\%), this implies that raising the interest differential by more than $10 \%$ of its mean increases foreign currency borrowing by just $2.4 \%$ of its mean $(25 \%)$.

Our model predicts that firms should not consider the nominal interest rate differential alone, but instead the net interest rate differential, taking into account the expected depreciation. Indeed, we find that the coefficient of Depreciation - Euro is negative and of similar magnitude to the coefficient of the nominal interest rate differential. ${ }^{22}$ Again this coefficient is significant for both clustered and non-clustered errors. However, our results also show that the coefficient of Depreciation - USD is not significant at all. These findings suggest that for those firms in our sample that are primarily motivated by interest rate differentials to take foreign currency loans, the euro may be the more relevant comparison currency.

Table 9 provides mixed results on the relevance of exchange rate volatility for firms' choices of loan denomination. Our results suggest that past volatility of depreciation vis-àvis the US dollar or euro does not affect firms' choices: the coefficients of Depreciation volatility are insignificant for both currencies. However, in line with our predictions, we do find that firms located in countries with fixed exchange rate regimes are more likely to take foreign currency loans. The coefficient of Peg is positive and significant in columns (1) and (2). Surprisingly, though, after controlling for the exchange rate regime we do not find that countries that are on track to join the European Union display higher levels of foreign currency borrowing. Finally, as predicted by Ize and Levy-Yeyati (2003), we find that higher levels of volatility of domestic inflation encourage foreign currency borrowing. This

\footnotetext{
${ }^{22}$ Indeed, a Wald test suggests that we cannot reject the hypothesis that the coefficients of Interest differential - Euro and Depreciation - Euro in Column (2) add up to zero.
} 
confirms the findings of Basso, Calvo-Gonzalez and Jurgilas (2007) and Luca and Petrova (2008) for aggregate credit dollarization.

In Panel B of Table 9 we examine the extent to which our results above could be driven by unobserved heterogeneity across countries. Table 4 shows that the macroeconomic conditions vary substantially across the countries in our sample. These differences may be correlated with institutional features of the banking sector or common characteristics of the firms within each country. To account for unobserved heterogeneity across countries, Panel B of Table 9 replicates our analysis including country fixed effects. The results show that the significance of most of our macroeconomic variables disappears when we control for country fixed effects. The coefficients of three of our measures of nominal interest rate differentials (Interest diff. - USD, - Euro, and - Loans) drop substantially and are no longer significant. The variable Depreciation - Euro also falls in magnitude and loses significance. The only macroeconomic variable that consistently retains a significant coefficient after including country fixed effects is domestic Inflation volatility. Note that despite our short observation period of three years, there is substantial time variation in our macroeconomic variables. For example, as shown in Table 4, nominal interest rate differentials drop on average from more than $10 \%$ in 2002:I to below $4 \%$ in 2005:II. Likewise, exchange rate movements against the euro vary from a depreciation of $8 \%$ in 2002:III to an appreciation of $2.8 \%$ in 2004:II. Thus our finding that the explanatory power of macroeconomic variables drops when we introduce country fixed effects cannot be accounted for by lack of variation in these variables. The results in Panel B of Table 9 therefore suggest that foreign currency borrowing by firms in our sample may be less related to variation in nominal interest rate differentials and exchange rate movements, than to differences in institutional settings across countries. 


\section{Sample Splits}

We check the robustness of our macroeconomic results by estimating coefficients for various subsamples in Table 10. First, we expect that the impact of interest rate differentials and exchange rate movements on loan denomination choice should be stronger for local currency earners than for foreign currency earners. In Panel A of the table we therefore conduct OLS regressions interacting each macroeconomic explanatory variable with the dummy variable Local currency earner. We conduct this analysis both for USD-related macro variables (Columns 1) and euro-related variables (Column 2). The results support our above findings that interest rate differentials and exchange rate movements do not drive foreign currency borrowing in our sample. Contrary to our expectations, we do not find that local currency earners react more strongly to changes in these macro variables than foreign currency earners. The interaction terms of Local currency earner with Interest differential, Depreciation, and Depreciation volatility, as well as with Inflation volatility, are all insignificant. Interestingly, we find that local currency earners are less likely than foreign currency earners to take foreign currency loans in countries that are on track to join the European Union. This result suggests that those firms that have (some) foreign currency income, rather than those that have none at all, are more likely to take foreign currency loans when the exchange rate environment becomes more stable.

One reason for the weak impact of the macroeconomic variables in Table 9 may be that the relevant foreign currency for firms differs across countries. Our full sample analysis assumes that the US dollar and the euro are equally important as reference currencies in all countries. Existing evidence suggests, however, that the euro is the most relevant foreign currency in Eastern European transition countries (Rosenberg and Tirpak (2008)), while the US dollar is more relevant in countries of the Commonwealth of Independent States 
(Brown, Rueda Maurer, Pak and Tynaev (2007), Luca and Petrova (2008)). In Panel A of Table 10 we therefore also repeat our full sample analysis, including the interaction terms of our macro variables with $E U$ (Columns 2 and 3) and CIS (Columns 3 and 4) respectively. Contrary to our expectations, we do not find that firms in European Union accession countries react more strongly to interest rate differentials and depreciation against the euro than firms in non-accession countries (Column 4). Moreover, we do not find that the loan currency choice of firms in CIS countries is more strongly affected by interest rate differentials and depreciation vis-à-vis the US dollar (Column 5).

[Table 10 here]

The impact of changes in macroeconomic conditions on foreign currency borrowing within a country may depend strongly on the level of the macroeconomic parameters of that country. This is not accounted for in our full sample analysis in Table 9, which reports marginal effects at the sample means only. In Panel C of Table 10 we therefore replicate our analysis of macroeconomic determinants for each country separately. The results in this panel confirm that changes in macroeconomic conditions have little impact on foreign currency borrowing within countries. We find, for example, that Interest differential - USD is only significant for 2 of 19 countries, while Depreciation - USD is only negative and significant for one country. Likewise Interest differential - Euro is only significant for 3 countries, while Depreciation - Euro is only significant for one country.

\section{Institutional Determinants of Loan Currency Denomination}

If interest rate differentials and exchange rate movements hardly affect the loan currency choice of firms in our sample, how can we explain the strong cross-country variation in foreign currency borrowing observed in our data? In Table 11 we examine the extent to which institutional differences across countries may be responsible for this 
variation. Our theoretical model suggests that foreign currency borrowing may be positively associated with strong foreign bank presence and weak corporate governance, which may both aggravate information asymmetries between firms and banks. In addition, we expect more foreign currency borrowing in countries with a higher degree of dollarization in the real economy. The demand for foreign currency loans should further be affected by the availability of alternative hedging instruments, such as forward contracts. Finally, the supply of foreign currency loans may be affected by regulations that limit the refinancing opportunities of banks abroad and their ability to hold open foreign currency positions.

\section{[Table 11 here]}

The results in Table 11 suggest that institutional characteristics do contribute to explaining cross-country differences in foreign currency borrowing. We find that in countries with higher Foreign bank presence and lower indices of Enterprise reform, firms are more likely to take foreign currency loans. These results suggest that information asymmetries may indeed foster foreign currency borrowing in our sample. However, the positive effect of foreign bank presence could also be due to the fact that foreign banks have easier access to funding in foreign currency, which increases the supply of loans in these currencies. Supporting this interpretation, we find that countries that impose Capital controls display lower levels of foreign currency borrowing, suggesting that these limit the supply of foreign currency loans by banks. Thus in line with the aggregate evidence by Rosenberg and Tirpak (2008) but in contrast to the bank-level evidence by Haiss, Paulhart and Rainer (2008), our results suggest that international funding is an important determinant of loan dollarization in transition countries.

The results in Table 11 further show that countries with more generous supervisory limits on open foreign currency positions of banks also display higher shares of foreign 
currency borrowing. This finding also supports the above results that supply-side constraints seem to be relevant in explaining the cross-country variation in our sample.

Our results do not confirm that foreign currency borrowing is more frequent in countries with higher degrees of real dollarization: the share of foreign currency deposits in a country (Forex deposits) does not bear the expected positive and significant coefficient. In addition, foreign currency loans are not more frequent in CIS countries, which are characterized by a higher degree of real dollarization. Further, in contrast to Luca and Petrova (2008), we do not find that the development of forward foreign currency markets affects foreign currency borrowing. This result supports our earlier conjecture that forward contracts are hardly relevant as alternative hedging instruments for our sample of small firms.

Finally, Table 11 confirms our previous results, that interest rate differentials and exchange rate movements cannot explain foreign currency borrowing in our sample. Controlling for institutional differences across countries, we find that our indicators of Interest differentials, Depreciation, and Depreciation volatility yield insignificant coefficients. Confirming our earlier results, we do, however, find that greater volatility of domestic inflation encourages foreign currency borrowing.

\section{Conclusion}

Motivated by policy concerns about the credit risks resulting from unhedged foreign currency loans, especially in opaque financial environments, we investigate how an information asymmetry between banks and firms in a theoretical framework - that also features the trade-off between the cost and the risk of debt - may determine the currency denomination of bank loans to firms. Banks may not know the currency in which firms have contracted their sales or the level of firm revenues. Foreign currency earners and local 
currency earners with distress costs that are small vis-à-vis the interest rate differential choose foreign currency loans if the foreign interest rate is lower. With imperfect information for the banks concerning the currency and level of firm revenues, we show that more local currency earners switch to foreign currency loans.

We then test these implications of our theoretical model by using a 2005 survey of 9,655 firms from 26 transition countries. We find strong evidence that firms with foreign currency earnings borrow more in foreign currency. However, we find only weak evidence that firms with lower distress costs and opaque firms are more likely to borrow in foreign currency.

At the country level, we find that neither interest rate advantages nor exchange rate movements explain foreign currency borrowing in our sample. We do however find that foreign bank presence, corporate governance and controls on incoming international capital flows explain cross-country differences in loan dollarization. Hence, employing reasonable firm and country proxies, we cannot confirm that "carry-trade behavior" is the key driver of the recently observed increase in foreign currency borrowing by small firms in transition economies. Our results do, however, support the conjecture that banking-sector structures and institutions that aggravate information asymmetries may be facilitating (unhedged) foreign currency borrowing. Thus, while our findings may partly allay some concerns of policymakers on foreign currency borrowing in these countries, policy innovations towards transparency may still be called for. 


\section{Table 1. Variable definitions}

Data Sources: AREAER: Annual report on Exchange Arrangements and Exchange Restrictions of the International Monetary Fund; BCJ: Basso, CalvoGonzalez and Jurgilas (2007); BEEPS: Business Environment and Enterprise Performance Survey in 2005 by the European Bank for Reconstruction and Development and the World Bank; CIAF: CIA Factbook; IFS: International Finance Statistics of the International Monetary Fund; TR: Transition report by the European Bank for Reconstruction and Development.

\begin{tabular}{|c|c|c|}
\hline Variable Name & Definition & Source \\
\hline Forex loan & $1=$ last loan of firm was in a foreign currency, $0=$ last loan of firm was in local currency. & BEEPS \\
\hline Duration & Duration of the loan, in months. & BEEPS \\
\hline Collateralized & $1=$ yes, $0=$ no. & BEEPS \\
\hline Collateral value & The value of collateral posted by the firm over loan size, in $\%$. & BEEPS \\
\hline Interest rate & Interest rate per annum, in $\%$. & BEEPS \\
\hline Exporter & $1=$ firm has export revenues, $0=$ otherwise. & BEEPS \\
\hline Sales to multinationals & $1=$ firm has domestic sales to multinational companies, $0=$ otherwise. & BEEPS \\
\hline Foreign firm & $1=$ at least $50 \%$ of ownership in foreign hands, $0=$ otherwise. & BEEPS \\
\hline Family firm & $1=$ firm is owned by sole proprietor or family, $0=$ otherwise. & BEEPS \\
\hline Security costs & Expenses for security services over sales. & BEEPS \\
\hline Debt & Share of short-term investment financed by debt. & BEEPS \\
\hline Audited firm & $1=$ firm has an external auditor, $0=$ otherwise. & BEEPS \\
\hline Income via bank & Share of firm revenues that are received through bank transfers. & BEEPS \\
\hline International accounting & $1=$ firm applies international accounting standards (IAS or USGAAP), $0=$ otherwise. & BEEPS \\
\hline Small firm & $1=$ less than 50 employees, $0=$ otherwise. & BEEPS \\
\hline Age & Age of firm at time of loan disbursement, in years. & BEEPS \\
\hline Interest diff. - USD (- Euro) & Domestic Tbill / money market rate minus US Tbill rate (Eurepo rate), in the past quarter. & IFS \\
\hline Interest diff. - loans (- deposits) & Difference in nominal interest rates on 1-year loans (deposits): local minus foreign currency rate, in the past quarter. & $\mathrm{BCJ}$ \\
\hline Depreciation - USD (- Euro) & Depreciation of local currency versus the US\$ (Euro), nominal, in $\%$, during the past quarter. & IFS \\
\hline Deprec. volatility - USD (- Euro) & Variance of monthly changes in the real exchange rate versus the US\$ (Euro), in \%, during the past 4 quarters. & IFS \\
\hline Peg & $1=$ country has crawling peg fixed peg or currency board exchange rate regime, $0=$ otherwise. & AREAER \\
\hline$E U$ & $1=$ country is or has completed negotiations to become EU member, $0=$ otherwise. & CIAF \\
\hline Inflation volatility & Variance of monthly changes in the consumer price index, in $\%$, during the past 4 quarters. & IFS \\
\hline Foreign banks & Assets share of foreign controlled banks in domestic banking system, in $\%$. & TR \\
\hline Enterprise reform & EBRD index of Enterprise reform. Scale: 1 to 4.33 . & TR \\
\hline Forex deposits & Share of deposits in the banking sector denominated in foreign currency, in $\%$. & $\mathrm{BCJ}$ \\
\hline CIS & $1=$ country is member of commonwealth of independent states, $0=$ otherwise. & CIAF \\
\hline Forward fx market & $1=$ country has developed forward foreign exchange market, $0=$ otherwise. & AREAER \\
\hline Capital controls & $1=$ country has controls on foreign borrowing by or foreign direct investment in domestic firms, $0=$ otherwise. & AREAER \\
\hline Open fx position & Maximum total open foreign exchange position of banks over capital, in $\%$. & AREAER \\
\hline
\end{tabular}


Table 2. Loan characteristics: Summary statistics

Forex loan: 1= last loan of firm was in a foreign currency, $0=$ last loan of firm was in local currency. Duration: Duration of the loan, in months. Collateralized: $1=$ yes, $0=$ no. Collateral value: The value of collateral posted by the firm over loan size, in \%. Interest rate: Interest rate per annum, in \%.

Panel A: Sample means by country

\begin{tabular}{l|rrrrrr}
\hline & Observations & Forex loan & Duration & Collateralized & Collateral & value \\
Country & 81 & 0.73 & 37.4 & 0.96 & 165 & 9.5 \\
\hline Albania & 140 & 0.29 & 22.3 & 0.74 & 133 & 14.8 \\
Armenia & 4 & 0.25 & 59.0 & 1.00 & 163 & 15.0 \\
Azerbaijan & 79 & 0.27 & 19.9 & 0.89 & 128 & 18.0 \\
Belarus & 94 & 0.02 & 35.4 & 0.97 & 208 & 10.2 \\
Bosnia & 102 & 0.29 & 37.6 & 0.88 & 144 & 11.1 \\
Bulgaria & 130 & 0.27 & 49.3 & 0.80 & 115 & 7.6 \\
Croatia & 84 & 0.07 & 33.3 & 0.82 & 108 & 9.3 \\
Czech Rep. & 69 & 0.28 & 51.3 & 0.90 & 132 & 6.7 \\
Estonia & 53 & 0.66 & 24.7 & 0.92 & 174 & 18.4 \\
Georgia & 262 & 0.24 & 30.5 & 0.92 & 155 & 13.2 \\
Hungary & 232 & 0.26 & 28.2 & 0.96 & 143 & 15.9 \\
Kazakhstan & 70 & 0.36 & 22.6 & 0.96 & 186 & 19.0 \\
Kyrgyzstan & 84 & 0.23 & 40.1 & 0.92 & 128 & 6.8 \\
Latvia & 69 & 0.25 & 32.1 & 0.84 & 114 & 5.7 \\
Lithuania & 35 & 0.46 & 20.4 & 0.94 & 199 & 10.9 \\
Macedonia & 134 & 0.25 & 18.5 & 0.93 & 140 & 20.9 \\
Moldova & 306 & 0.14 & 29.1 & 0.79 & 119 & 12.6 \\
Poland & 254 & 0.39 & 25.3 & 0.93 & 143 & 18.0 \\
Romania & 177 & 0.12 & 23.2 & 0.90 & 136 & 17.4 \\
Russia & 114 & 0.19 & 21.0 & 0.90 & 174 & 13.3 \\
Serbia & 64 & 0.06 & 39.7 & 0.83 & 103 & 7.6 \\
Slovak Rep. & 125 & 0.25 & 40.7 & 0.60 & 89 & 6.3 \\
Slovenia & 38 & 0.26 & 20.5 & 0.84 & 151 & 24.5 \\
Tajikistan & 218 & 0.23 & 18.8 & 0.83 & 160 & 20.4 \\
Ukraine & 87 & 0.06 & 20.9 & 0.77 & 95 & 22.8 \\
Uzbekistan & 3,105 & 0.25 & 29.0 & 0.87 & 140 & 14.2 \\
\hline Total & & & & & &
\end{tabular}


Panel B: Sample means by period

\begin{tabular}{|c|c|c|c|c|c|c|}
\hline Year:Quarter & Observations & Forex loan & Duration & Collateralized & $\begin{array}{r}\text { Collateral } \\
\text { value }\end{array}$ & Interest \\
\hline 2002:I & 92 & 0.24 & 40.94 & 0.89 & 142.67 & 15.36 \\
\hline 2002:II & 120 & 0.28 & 37.49 & 0.89 & 129.81 & 13.07 \\
\hline 2002:III & 56 & 0.27 & 34.57 & 0.88 & 130.98 & 15.13 \\
\hline 2002:IV & 67 & 0.25 & 41.16 & 0.87 & 132.06 & 13.06 \\
\hline 2003:I & 142 & 0.28 & 30.68 & 0.89 & 132.59 & 15.07 \\
\hline 2003:II & 166 & 0.25 & 28.16 & 0.84 & 142.24 & 14.26 \\
\hline 2003:III & 120 & 0.28 & 30.65 & 0.88 & 154.46 & 15.11 \\
\hline 2003:IV & 115 & 0.27 & 35.63 & 0.83 & 130.33 & 13.15 \\
\hline 2004:I & 354 & 0.21 & 24.86 & 0.86 & 140.87 & 14.75 \\
\hline 2004:II & 441 & 0.24 & 26.86 & 0.88 & 141.08 & 14.41 \\
\hline 2004:III & 399 & 0.31 & 30.39 & 0.85 & 144.11 & 13.83 \\
\hline 2004:IV & 489 & 0.22 & 27.93 & 0.88 & 144.26 & 14.16 \\
\hline 2005:I & 484 & 0.23 & 25.19 & 0.86 & 134.59 & 13.73 \\
\hline 2005:II & 60 & 0.22 & 27.55 & 0.88 & 134.04 & 13.25 \\
\hline
\end{tabular}

Panel C: Pairwise correlations

\begin{tabular}{lrrrrr}
\hline & Forex loan & Duration & Collateralized & Collateral value & Interest \\
\hline Forex Loan & 1.00 & & & & \\
Duration & 0.15 & 1.00 & & & \\
Collateralized & 0.01 & 0.06 & 1.00 & & \\
Collateral value & 0.04 & 0.00 & 0.63 & 1.00 & \\
Interest & -0.13 & -0.22 & 0.07 & 0.09 & 1.00 \\
\hline
\end{tabular}




\section{Table 3. Firm characteristics: Summary statistics}

Exporter: $1=$ firm has export revenues, $0=$ otherwise. Sales to multinationals: $1=$ firm has domestic sales to multinational companies, $0=$ otherwise. Foreign firm: $1=$ at least $50 \%$ of ownership in foreign hands, $0=$ otherwise. Family firm: $1=$ firm is owned by sole proprietor or family, $0=$ otherwise. Security costs: Expenses for security services over sales, in \%. Debt: Share of short-term investment financed by debt. Audited firm: $1=$ firm has an external auditor, $0=$ otherwise. Income via bank: Share of firm revenues that are received through bank transfers. International accounting: $1=$ firm applies international accounting standards (IAS or USGAAP), $0=$ otherwise. Small firm: $1=$ less than 50 employees, $0=$ otherwise. Age: Age of firm at loan disbursement, in years.

\section{Panel A: Sample means by choice of loan denomination}

The reported difference tests are standard t-tests. *, **, and *** indicate significance at the $10 \%$, $5 \%$, and $1 \%$ levels, respectively.

\begin{tabular}{|c|c|c|c|c|c|}
\hline & Total & $\begin{array}{r}\text { Firms w/ local } \\
\text { currency loan }\end{array}$ & $\begin{array}{r}\text { Firms w/ foreign } \\
\text { currency loan }\end{array}$ & Difference tests & \\
\hline Exporter & 0.34 & 0.31 & 0.43 & $\mathrm{t}(3,101)=6.25$ & *** \\
\hline Sales to multinationals & 0.18 & 0.17 & 0.24 & $\mathrm{t}(3,020)=4.46$ & $* * *$ \\
\hline Foreign firm & 0.11 & 0.08 & 0.20 & $\mathrm{t}(3,105)=9.03$ & $* * *$ \\
\hline Family firm & 0.72 & 0.73 & 0.70 & $\mathrm{t}(3,011)=1.20$ & \\
\hline Security costs & 0.74 & 0.69 & 0.93 & $\mathrm{t}(3,105)=3.50$ & $* * *$ \\
\hline Debt & 0.38 & 0.38 & 0.40 & $\mathrm{t}(3,054)=1.21$ & \\
\hline Audited firm & 0.53 & 0.51 & 0.59 & $\mathrm{t}(3,071)=4.20$ & $* * *$ \\
\hline Income via bank & 0.57 & 0.58 & 0.55 & $\mathrm{t}(3,099)=1.94$ & $*$ \\
\hline International accounting & 0.22 & 0.19 & 0.31 & $\mathrm{t}(3,105)=7.16$ & $* * *$ \\
\hline Small firm & 0.61 & 0.62 & 0.57 & $\mathrm{t}(3,105)=2.49$ & $* *$ \\
\hline Age & 15.69 & 16.19 & 14.19 & $\mathrm{t}(3103)=2.52$ & $* *$ \\
\hline
\end{tabular}


Panel B: Pairwise correlations

\begin{tabular}{|c|c|c|c|c|c|c|c|c|c|c|c|}
\hline & 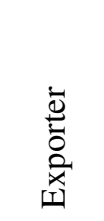 & 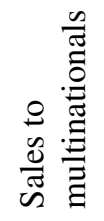 & 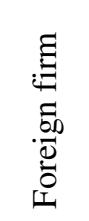 & 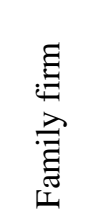 & 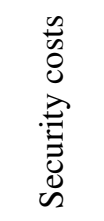 & $\frac{\overrightarrow{0}}{0}$ & 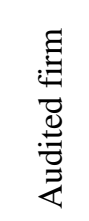 & 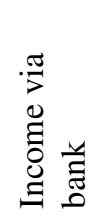 & 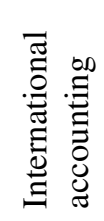 & 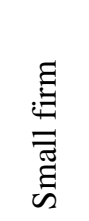 & $\underset{8}{\stackrel{8}{\&}}$ \\
\hline Exporter & 1 & & & & & & & & & & \\
\hline Sales to multinationals & .206 & 1 & & & & & & & & & \\
\hline Foreign firm & .205 & .178 & 1 & & & & & & & & \\
\hline Family firm & -.152 & -.058 & -.266 & 1 & & & & & & & \\
\hline Security costs & -.025 & .037 & .024 & -.039 & 1 & & & & & & \\
\hline Debt & .078 & .094 & .037 & -.039 & .004 & 1 & & & & & \\
\hline Audited firm & .189 & .157 & .179 & -.248 & .003 & .041 & 1 & & & & \\
\hline Income via bank & .290 & .119 & .107 & -.157 & -.009 & .065 & .167 & 1 & & & \\
\hline International accounting & .183 & .115 & .162 & -.134 & .026 & .058 & .202 & .055 & 1 & & \\
\hline Small firm & -.286 & -.068 & -.183 & .364 & -.075 & -.039 & -.314 & -.182 & -.231 & 1 & \\
\hline Age & .216 & .008 & -.020 & -.320 & .003 & -.015 & .196 & .106 & .137 & -.358 & 1 \\
\hline
\end{tabular}


Table 4. Macroeconomic explanatory variables: Summary statistics

The table displays four measures of the nominal Interest rate differential between local currency and foreign currency funds per country, in \%. USD: Domestic Tbill rate minus US Tbill rate. Euro: Domestic Tbill rate minus Eurepo rate. Loans: Interest rate differential on loans. Deposits: Interest rate differential on deposits. The table further displays the Depreciation in \% of the local currency against the US dollar (Euro). Finally the table displays our measures of monetary volatility: Depreciation volatility: Variance of month on month changes in the real exchange rate vis-à-vis the USD (Euro). Inflation volatility: Variance of month on month changes in the consumer price index.

Panel A: Sample means by country, $2002-2005$

\begin{tabular}{|c|c|c|c|c|c|c|c|c|c|}
\hline \multirow[b]{2}{*}{ Country } & \multicolumn{4}{|c|}{ Interest rate differential } & \multicolumn{2}{|c|}{ Depreciation } & \multicolumn{2}{|c|}{ Deprec. volatility } & \multirow{2}{*}{$\begin{array}{l}\text { Inflation } \\
\text { volatility }\end{array}$} \\
\hline & - USD & - Euro & - Loans & - Deposits & -USD & -Euro & -USD & -Euro & \\
\hline Albania & 6.7 & 5.5 & 6.4 & 5.6 & -2.6 & -0.1 & 9.3 & 6.8 & 2.0 \\
\hline Armenia & 9.2 & 8.0 & 0.8 & 2.6 & -1.3 & 1.3 & 5.7 & 8.4 & 5.1 \\
\hline Azerbaijan & 7.7 & 6.5 & -2.6 & -0.2 & 0.2 & 2.9 & 0.8 & 7.3 & 0.8 \\
\hline Belarus & 31.8 & 30.7 & 9.0 & 20.2 & 2.8 & 5.5 & 1.1 & 8.7 & 1.2 \\
\hline \multicolumn{10}{|l|}{ Bosnia } \\
\hline Bulgaria & 1.8 & 0.7 & 3.6 & 1.0 & -2.3 & 0.0 & 7.7 & 1.2 & 1.2 \\
\hline Croatia & 1.9 & 0.8 & 4.1 & 1.3 & -2.4 & 0.0 & 8.9 & 3.4 & 0.2 \\
\hline Czech Rep. & 1.4 & 0.3 & 1.1 & 0.0 & -3.1 & -0.8 & 17.9 & 5.5 & 0.2 \\
\hline Estonia & 1.7 & 0.5 & 1.7 & 0.1 & -2.3 & 0.0 & 7.5 & 0.3 & 0.2 \\
\hline Georgia & 32.1 & 31.0 & 3.0 & -3.8 & -0.8 & 1.8 & 4.3 & 8.4 & 1.4 \\
\hline Hungary & 8.0 & 6.8 & 7.4 & 6.1 & -2.6 & -0.2 & 9.5 & 3.4 & 0.3 \\
\hline Kazakhstan & 3.6 & 2.5 & 3.7 & 1.2 & -0.8 & 1.9 & 0.9 & 8.3 & 0.2 \\
\hline Kyrgyzstan & 6.2 & 5.0 & 8.2 & 5.6 & -1.0 & 1.7 & 6.6 & 12.8 & 1.1 \\
\hline Latvia & 1.7 & 0.6 & 4.0 & 1.2 & -0.9 & 1.6 & 2.1 & 3.3 & 0.2 \\
\hline Lithuania & 1.1 & -0.1 & 1.5 & -0.2 & -2.8 & -0.4 & 6.9 & 2.3 & 0.2 \\
\hline Macedonia & 6.8 & 5.6 & 4.6 & 4.0 & -2.3 & 0.1 & 8.3 & 1.4 & 0.5 \\
\hline Moldova & 8.9 & 7.8 & 10.0 & 10.6 & -0.1 & 2.7 & 2.9 & 10.4 & 1.1 \\
\hline Poland & 5.9 & 4.7 & 6.1 & 2.7 & -1.9 & 0.5 & 10.1 & 8.6 & 0.1 \\
\hline Romania & 20.6 & 19.5 & 17.2 & 11.2 & -0.4 & 2.2 & 4.5 & 5.1 & 0.3 \\
\hline Russia & 5.4 & 4.3 & 4.0 & & -0.4 & 2.3 & 1.3 & 8.4 & 0.4 \\
\hline Serbia & 15.4 & 14.3 & & & -0.2 & 2.4 & 7.7 & 2.5 & 1.8 \\
\hline Slovak Rep. & 4.7 & 3.6 & 1.7 & 0.9 & -3.1 & -0.7 & 8.0 & 3.8 & 1.1 \\
\hline Slovenia & 5.0 & 3.9 & 3.7 & 1.6 & -1.7 & 0.7 & 7.7 & 1.2 & 0.2 \\
\hline Tajikistan & 15.9 & 14.7 & -0.7 & 0.0 & 1.8 & 4.4 & & & \\
\hline Ukraine & 5.6 & 4.5 & 8.8 & 1.8 & -0.1 & 2.6 & 0.9 & 7.3 & 0.8 \\
\hline Uzbekistan & & & & & & & & & \\
\hline
\end{tabular}


Panel B: Sample means by quarter

\begin{tabular}{lrrrrrrrrr}
\hline & \multicolumn{3}{c}{ Interest rate differential } & \multicolumn{3}{c}{ Depreciation } & \multicolumn{2}{c}{ Deprec. volatility } & Inflation \\
Year:Quarter & - USD & - Euro & - Loans & - Deposits & -USD & -Euro & -USD & -Euro & volatility \\
\hline 2002:I & 12.0 & 10.5 & 6.7 & 4.9 & 1.7 & -1.9 & 3.4 & 6.1 & 1.1 \\
2002:II & 11.6 & 10.0 & 5.0 & 4.6 & 2.1 & 1.1 & 3.2 & 5.8 & 1.1 \\
2002:III & 10.6 & 8.9 & 4.5 & 3.8 & -5.3 & 8.2 & 3.5 & 7.0 & 1.0 \\
2002:IV & 10.5 & 8.9 & 4.6 & 3.7 & 1.0 & -0.2 & 3.8 & 5.8 & 1.1 \\
2003:I & 10.1 & 8.3 & 4.8 & 2.8 & -2.8 & 3.4 & 4.3 & 4.7 & 1.0 \\
2003:II & 9.1 & 7.6 & 3.7 & 3.4 & -0.5 & 3.4 & 4.4 & 4.5 & 1.0 \\
2003:III & 9.6 & 8.3 & 4.9 & 3.2 & -3.6 & 1.1 & 7.1 & 4.7 & 0.9 \\
2003:IV & 9.4 & 8.2 & 4.4 & 3.4 & -0.3 & 1.7 & 9.6 & 6.2 & 0.8 \\
2004:I & 9.6 & 8.4 & 4.3 & 3.2 & -4.4 & 3.7 & 10.0 & 6.5 & 0.9 \\
2004:II & 8.0 & 6.9 & 4.4 & 3.1 & 0.4 & -2.8 & 10.4 & 7.8 & 0.8 \\
2004:III & 7.0 & 6.0 & 4.2 & 2.6 & -0.3 & -0.9 & 7.9 & 6.4 & 0.9 \\
2004:IV & 5.9 & 5.3 & 4.1 & 2.4 & -1.2 & 0.9 & 5.2 & 4.9 & 0.7 \\
2005:I & 4.9 & 4.7 & 4.1 & 2.3 & -6.4 & 2.8 & 5.4 & 4.2 & 0.7 \\
2005:II & 3.5 & 3.9 & 4.1 & 2.1 & 2.6 & -2.4 & 6.6 & 4.6 & 0.7 \\
\hline
\end{tabular}

\section{Panel C: Pairwise correlations}

\begin{tabular}{|c|c|c|c|c|c|c|c|c|c|}
\hline \multirow[b]{2}{*}{ Year:Quarter } & \multicolumn{4}{|c|}{ Interest rate differential } & \multicolumn{2}{|c|}{ Depreciation } & \multicolumn{2}{|c|}{ Deprec. volatility } & \multirow{2}{*}{$\begin{array}{l}\text { Inflation } \\
\text { volatility }\end{array}$} \\
\hline & - USD & - Euro & - Loans & - Deposits & - USD & - Euro & $-\mathrm{USD}$ & - Euro & \\
\hline Int.diff. - USD & 1 & & & & & & & & \\
\hline Int.diff. - Euro & .996 & 1 & & & & & & & \\
\hline Int.diff. - Loans & .265 & .278 & 1 & & & & & & \\
\hline Int.diff. - Dep. & .517 & .523 & .671 & 1 & & & & & \\
\hline Deprec. - USD & .526 & .551 & .101 & .236 & 1 & & & & \\
\hline Deprec. - Euro & .480 & .467 & .017 & .186 & .515 & 1 & & & \\
\hline Vol. - USD & .253 & .267 & .076 & .114 & .331 & .200 & 1 & & \\
\hline Vol. - Euro & .577 & .586 & .240 & .333 & .562 & .491 & .588 & 1 & \\
\hline Infl. Vol. & .236 & .244 & .112 & .299 & .250 & .166 & .584 & .622 & 1 \\
\hline
\end{tabular}


Table 5. Exchange rate regime and political affiliation

The table summarizes the exchange rate regime and political affiliation per country for our observation period of 2002:1 to 2005:2. All entries are denoted in Year:Quarter. Float: exchange rate regime is independently floating or managed float. Crawling Peg: exchange rate regime is a crawling peg or crawling band arrangement. Fixed peg: exchange rate regime is a conventional peg or currency board arrangement. EU: Country has completed negotiations to become EU member. CIS: Country is member of the Commonwealth of Independent States.

\begin{tabular}{|c|c|c|c|c|c|}
\hline Country & Float & Crawl Peg & Fixed Peg & EU & CIS \\
\hline Albania & 2002:I-2005:II & & & & \\
\hline Armenia & 2002:I-2005:II & & & & from 1992:I \\
\hline Azerbaijan & 2002:I-2005:II & & & & from 1993:III \\
\hline Belarus & & 2002:I-2005:II & & & from 1992:I \\
\hline Bosnia & & & 2002:I-2005:II & & \\
\hline Bulgaria & & & 2002:I-2005:II & from 2005:I & \\
\hline Croatia & 2002:I-2005:II & & & & \\
\hline Czech Rep. & 2002:I-2005:II & & & from 2003:I & \\
\hline Estonia & & & 2002:I-2005:II & from 2003:I & \\
\hline Georgia & 2002:I-2005:II & & & & from 1994:I \\
\hline Hungary & & & 2002:I-2005:II & from 2003:I & \\
\hline Kazakhstan & 2002:I-2005:II & & & & from 1992:I \\
\hline Kyrgyzstan & 2002:I-2005:II & & & & from 1992:I \\
\hline Latvia & & & 2002:I-2005:II & from 2003:I & \\
\hline Lithuania & & & 2002:I-2005:II & from 2003:I & \\
\hline Macedonia & & & 2002:I-2005:II & & \\
\hline Moldova & 2002:I-2005:II & & & & from 1992:I \\
\hline Poland & 2002:I-2005:II & & & from 2003:I & \\
\hline Romania & & 2002:I-2005:II & & from 2005:I & \\
\hline Russia & 2002:I-2005:II & & & & from 1992:I \\
\hline Serbia & from 2003:I & & & & \\
\hline Slovak Rep. & 2002:I-2005:II & & & from 2003:I & \\
\hline Slovenia & & 2002:I-2004:II & from 2004:III & from 2003:I & \\
\hline Tajikistan & 2002:I-2005:II & & & & from 1992:I \\
\hline Ukraine & & & 2002:I-2005:II & & from 1992:I \\
\hline Uzbekistan & 2002:I-2005:II & & & & from 1992:I \\
\hline
\end{tabular}




\section{Table 6. Banking sector and institutional variables: Summary statistics}

The table displays summary statistics for our banking sector and institutional level explanatory variables. Foreign banks: Assets share of foreign controlled banks in domestic banking system, in \%. Enterprise reform: EBRD index of Enterprise reform. Forex deposits: Share of deposits in the banking sector denominated in foreign currency, in \%. Forward fx market: 1= country has developed forward foreign exchange market, $0=$ otherwise. Capital controls: $1=$ country has controls on foreign borrowing by or foreign direct investment in domestic firms, $0=$ otherwise. Open $f x$ position: Maximal open foreign exchange position of banks over capital, in \%.

Panel A: Sample means by country, $2002-2005$

\begin{tabular}{|c|c|c|c|c|c|c|}
\hline Country & $\begin{array}{r}\text { Foreign } \\
\text { banks }\end{array}$ & $\begin{array}{l}\text { Enterprise } \\
\text { reform }\end{array}$ & $\begin{array}{r}\text { Forex } \\
\text { deposits }\end{array}$ & $\begin{array}{r}\text { Forward fx } \\
\text { market }\end{array}$ & $\begin{array}{r}\text { Capital } \\
\text { controls }\end{array}$ & $\begin{array}{l}\text { Open } \mathrm{fx} \\
\text { position }\end{array}$ \\
\hline Albania & 66.4 & 2 & 31.2 & 0 & 0 & 30 \\
\hline Armenia & 53.4 & 2.3 & 73.6 & 0 & 0 & 24 \\
\hline Azerbaijan & 5.3 & 1.91 & 49.5 & 0.71 & 1 & 20 \\
\hline Belarus & 16.2 & 1 & 57.1 & 0 & 1 & 20 \\
\hline Bosnia & 80.8 & 1.91 & 51.2 & 0 & 0.71 & \\
\hline Bulgaria & 79.1 & 2.59 & 50.1 & 0 & 1 & 30 \\
\hline Croatia & 90.9 & 2.83 & 66.4 & 0 & 0.43 & 20 \\
\hline Czech Rep. & 85.5 & 3.3 & 10.8 & 1 & 1 & 20 \\
\hline Estonia & 97.9 & 3.36 & 28.6 & 1 & 1 & 30 \\
\hline Georgia & 35.1 & 2.04 & 95.6 & 0 & 0 & \\
\hline Hungary & 77.9 & 3.36 & 16.4 & 1 & 0 & 30 \\
\hline Kazakhstan & 28.7 & 2 & 52.4 & 1 & 0 & 47 \\
\hline Kyrgyzstan & 62.5 & 2 & 0.6 & 0 & 0 & 20 \\
\hline Latvia & 49.5 & 2.91 & 40.1 & 1 & 0 & 20 \\
\hline Lithuania & 93.8 & 3 & 37.1 & 1 & 0 & 30 \\
\hline Macedonia & 46.8 & 2.3 & 52.6 & 0.71 & 0 & 50 \\
\hline Moldova & 32.9 & 1.83 & 50.7 & 0 & 0.57 & 20 \\
\hline Poland & 71.6 & 3.36 & 17.1 & 1 & 1 & \\
\hline Romania & 55.9 & 2.04 & 44.9 & 0 & 0.29 & 20 \\
\hline Russia & 7.8 & 2.3 & 38.5 & 1 & 1 & 20 \\
\hline Serbia & 38.9 & 2.04 & 62.1 & 0 & 0.29 & 30 \\
\hline Slovak Rep. & 93.1 & 3.36 & 15.3 & 0 & 0 & 18 \\
\hline Slovenia & 19.2 & 3 & 32.8 & 1 & 0 & 20 \\
\hline Tajikistan & 4.6 & 1.7 & 55.6 & 0 & 1 & 23 \\
\hline Ukraine & 13.5 & 2 & 32.9 & 0 & 0 & 30 \\
\hline Uzbekistan & 4.0 & 1.7 & & 0 & 1 & \\
\hline
\end{tabular}


Panel B: Sample means by quarter

\begin{tabular}{lrrrrrr}
\hline Year:Quarter & $\begin{array}{r}\text { Foreign } \\
\text { banks }\end{array}$ & $\begin{array}{r}\text { Enterprise } \\
\text { reform }\end{array}$ & $\begin{array}{r}\text { Forex } \\
\text { deposits }\end{array}$ & $\begin{array}{r}\text { Forward fx } \\
\text { market }\end{array}$ & $\begin{array}{r}\text { Capital } \\
\text { controls }\end{array}$ & $\begin{array}{r}\text { Open fx } \\
\text { position }\end{array}$ \\
\hline 2002:I & 46.8 & 2.34 & 45.7 & 0.35 & 0.46 & 27 \\
2002:II & 46.8 & 2.34 & 46.6 & 0.35 & 0.46 & 27 \\
2002:III & 46.8 & 2.34 & 45.6 & 0.35 & 0.46 & 27 \\
2002:IV & 46.8 & 2.34 & 45.1 & 0.35 & 0.46 & 27 \\
2003:I & 51.4 & 2.38 & 44.8 & 0.42 & 0.42 & 26 \\
2003:II & 51.4 & 2.38 & 42.7 & 0.42 & 0.42 & 26 \\
2003:III & 51.4 & 2.38 & 41.8 & 0.42 & 0.42 & 26 \\
2003:IV & 51.4 & 2.38 & 42.1 & 0.42 & 0.42 & 26 \\
2004:I & 53.5 & 2.39 & 41.7 & 0.42 & 0.42 & 27 \\
2004:II & 53.5 & 2.39 & 41.0 & 0.42 & 0.42 & 27 \\
2004:III & 53.5 & 2.39 & 40.8 & 0.42 & 0.42 & 27 \\
2004:IV & 53.5 & 2.39 & 41.0 & 0.42 & 0.42 & 27 \\
2005:I & 58.2 & 2.5 & 40.6 & 0.42 & 0.42 & 25 \\
2005:II & 58.2 & 2.5 & 41.2 & 0.42 & 0.42 & 25 \\
\hline
\end{tabular}

\section{Panel C: Pairwise correlations}

\begin{tabular}{lrrrrrr}
\hline & $\begin{array}{r}\text { Foreign } \\
\text { banks }\end{array}$ & $\begin{array}{r}\text { Enterprise } \\
\text { reform }\end{array}$ & $\begin{array}{r}\text { Forex } \\
\text { deposits }\end{array}$ & $\begin{array}{r}\text { Forward } \\
\text { fx market }\end{array}$ & $\begin{array}{r}\text { Capital } \\
\text { controls }\end{array}$ & $\begin{array}{r}\text { Open fx } \\
\text { position }\end{array}$ \\
\hline Foreign banks & 1 & & & & & \\
Enterprise reform & 0.66 & 1 & & & & \\
Forex deposits & -0.34 & -0.49 & 1 & & & \\
Forward fx market & 0.15 & 0.59 & -0.42 & 1 & & \\
Capital controls & -0.14 & -0.14 & -0.04 & 0.03 & 1 & \\
Open fx position & 0.02 & -0.05 & 0.15 & 0.23 & -0.36 & \\
\hline
\end{tabular}


Table 7. Firm-level determinants of foreign currency borrowing

The table reports results of probit estimates. The dependent variable Forex loan equals one if the firm's last loan is denominated in foreign currency and zero if this loan is in local currency. All explanatory variables are defined in Table 1 . Each regression includes six sector dummies. The table displays the marginal effects calculated at sample means. T-statistics are reported in parentheses. Standard errors are adjusted for cluster effects at the country level. *,**, and *** indicate significance at the $10 \%, 5 \%$, and $1 \%$ levels, respectively.

\begin{tabular}{lrrrr}
\hline & No fixed effects & $\begin{array}{r}(1) \\
\text { Country } \\
\text { fixed effects }\end{array}$ & $\begin{array}{r}\text { Country-year } \\
\text { fixed effects }\end{array}$ & $\begin{array}{r}\text { Country-quarter } \\
\text { fixed effects }\end{array}$ \\
\hline Exporter & 0.077 & 0.081 & 0.081 & 0.091 \\
Sales to multinationals & {$[4.10]^{* * *}$} & {$[4.46]^{* * *}$} & {$[4.37]^{* * *}$} & {$[3.99]^{* * *}$} \\
& 0.050 & 0.054 & 0.046 & 0.040 \\
Foreign firm & {$[1.76]^{*}$} & {$[1.93]^{*}$} & {$[1.63]$} & {$[1.27]$} \\
& 0.173 & 0.200 & 0.210 & 0.246 \\
Family firm & {$[4.38]^{* * *}$} & {$[5.54]^{* * *}$} & {$[5.79]^{* * *}$} & {$[6.63]^{* * *}$} \\
& 0.033 & 0.030 & 0.034 & 0.040 \\
Security costs & {$[1.19]$} & {$[1.28]$} & {$[1.50]$} & {$[1.47]$} \\
& 0.014 & 0.010 & 0.014 & 0.016 \\
Debt & {$[3.04]^{* * *}$} & {$[2.78]^{* * *}$} & {$[3.86]^{* * *}$} & {$[4.09]^{* * *}$} \\
& 0.011 & 0.024 & 0.034 & 0.046 \\
Audited firm & {$[0.48]$} & {$[1.21]$} & {$[1.65]^{*}$} & {$[1.76]^{*}$} \\
& 0.034 & 0.012 & 0.011 & 0.018 \\
Income via bank & {$[0.97]$} & {$[0.57]$} & {$[0.47]$} & {$[0.71]$} \\
& -0.089 & -0.021 & -0.033 & -0.047 \\
International accounting & {$[2.58]^{* * *}$} & {$[0.74]$} & {$[1.19]$} & {$[1.46]$} \\
& 0.081 & 0.053 & 0.058 & 0.079 \\
Small firm & {$[2.50]^{* *}$} & {$[1.95]^{*}$} & {$[2.01]^{* *}$} & {$[2.17]^{* *}$} \\
& -0.008 & -0.022 & -0.034 & -0.027 \\
Age & {$[0.33]$} & {$[0.79]$} & {$[1.16]$} & {$[0.79]$} \\
& -0.002 & -0.001 & -0.001 & -0.002 \\
Duration & {$[3.16]^{* * *}$} & {$[2.01]^{* *}$} & {$[2.15]^{* *}$} & {$[2.18]^{* *}$} \\
& 0.002 & 0.002 & 0.003 & 0.003 \\
Collateralized & {$[5.29]^{* * *}$} & {$[5.05]^{* * *}$} & {$[4.51]^{* * *}$} & {$[4.75]^{* * *}$} \\
& 0.031 & -0.006 & -0.007 & -0.009 \\
\hline Observations & {$[0.78]$} & {$[0.16]$} & {$[0.18]$} & {$[0.21]$} \\
\hline Sector fixed effects & 2,779 & 2,779 & 2,679 & 2,381 \\
\hline
\end{tabular}




\section{Table 8. Firm-level determinants: Subsamples}

The dependent variable Forex loan equals one if the firm's last loan is denominated in foreign currency and zero if this loan is in local currency. The table contrasts estimated coefficients for subsamples of firms, whereby our sample is split based on the income structure of firms and the dollarization level of the country the firms is situated in. Local currency earners are firms that have no export sales, no sales to multinationals, and no majority foreign owner and are situated in weakly dollarized countries. Foreign currency earners are all other firms. Weakly dollarized countries have a mean share of foreign currency deposits in the banking system of $50 \%$ or less for the observation period. Floating exchange rate are those firms situated in a country which has a floating exchange rate. Pegged exchange rate are those firms situated in countries with a currency board, fixed peg or crawling peg regime. Each regression includes country fixed effects and six sector dummies. T-statistics are reported in parentheses. Standard errors are adjusted for cluster effects at the country level. *,**, and *** indicate significance at the $10 \%, 5 \%$, and $1 \%$ levels, respectively.

\section{Panel A: Probit estimates for subsamples}

Panel A reports probit estimates for subsamples as defined above. The table displays the marginal effects calculated at sample means.

\begin{tabular}{|c|c|c|c|c|}
\hline & (1) & (2) & (3) & (4) \\
\hline & $\begin{array}{r}\text { Local currency } \\
\text { earners }\end{array}$ & $\begin{array}{r}\text { Foreign currency } \\
\text { earners }\end{array}$ & $\begin{array}{r}\text { Floating exchange } \\
\text { rate }\end{array}$ & $\begin{array}{r}\text { Pegged exchange } \\
\text { rate }\end{array}$ \\
\hline \multirow[t]{2}{*}{ Exporter } & & & 0.074 & 0.097 \\
\hline & & & {$[3.37]^{* * *}$} & {$[2.77] * * *$} \\
\hline \multirow[t]{2}{*}{ Sales to multinationals } & & & 0.093 & 0.013 \\
\hline & & & {$[2.62]^{* * *}$} & [0.56] \\
\hline \multirow[t]{2}{*}{ Foreign firm } & & & 0.123 & 0.280 \\
\hline & & & {$[4.18]^{* * *}$} & {$[5.72] * * *$} \\
\hline \multirow[t]{2}{*}{ Family firm } & 0.034 & -0.008 & 0.029 & 0.032 \\
\hline & {$[0.75]$} & {$[0.28]$} & {$[0.83]$} & {$[0.92]$} \\
\hline \multirow[t]{2}{*}{ Security costs } & 0.009 & 0.011 & 0.009 & 0.010 \\
\hline & {$[0.96]$} & {$[2.07] * *$} & {$[2.67]^{* * *}$} & [1.17] \\
\hline \multirow[t]{2}{*}{ Debt } & 0.015 & 0.033 & 0.019 & 0.034 \\
\hline & {$[0.48]$} & [1.16] & {$[0.57]$} & {$[1.55]$} \\
\hline \multirow[t]{2}{*}{ Audited firm } & -0.029 & 0.052 & 0.011 & 0.020 \\
\hline & {$[1.37]$} & {$[1.82]^{*}$} & {$[0.38]$} & {$[0.76]$} \\
\hline \multirow[t]{2}{*}{ Income via bank } & -0.024 & -0.009 & -0.040 & 0.007 \\
\hline & {$[0.71]$} & [0.19] & [0.93] & [0.19] \\
\hline \multirow[t]{2}{*}{ International accounting } & 0.001 & 0.092 & 0.072 & 0.010 \\
\hline & {$[0.02]$} & {$[3.41]^{* * *}$} & {$[2.57] * *$} & {$[0.22]$} \\
\hline \multirow[t]{2}{*}{ Small firm } & -0.059 & -0.010 & -0.027 & -0.026 \\
\hline & {$[1.62]$} & {$[0.27]$} & {$[0.73]$} & {$[0.58]$} \\
\hline \multirow[t]{2}{*}{ Age } & -0.002 & -0.002 & -0.001 & -0.002 \\
\hline & {$[1.34]$} & {$[2.23] * *$} & {$[0.88]$} & {$[1.93]^{*}$} \\
\hline \multirow[t]{2}{*}{ Duration } & 0.002 & 0.003 & 0.001 & 0.004 \\
\hline & {$[2.93]^{* * *}$} & {$[5.76]^{* * *}$} & {$[3.60]^{* * *}$} & {$[7.93] * * *$} \\
\hline \multirow[t]{2}{*}{ Collateralized } & 0.064 & -0.052 & -0.079 & 0.091 \\
\hline & {$[1.28]$} & {$[1.00]$} & {$[1.80]^{*}$} & {$[1.71]^{*}$} \\
\hline Observations & 844 & 1,791 & 844 & 1,791 \\
\hline Sector fixed effects & yes & yes & yes & yes \\
\hline Country fixed effects & yes & yes & yes & yes \\
\hline Clustered errors & yes & yes & yes & yes \\
\hline
\end{tabular}


Panel B: OLS estimates with interaction terms

Panel B reports results from OLS estimates for our full sample.

\begin{tabular}{lrrr}
\hline & $(1)$ & $(2)$ & $(3)$ \\
\hline Exporter & 0.074 & 0.063 & 0.092 \\
& {$[4.01]^{* * *}$} & {$[2.69]^{* *}$} & {$[2.94]^{* * *}$} \\
Sales to multinationals & 0.049 & 0.033 & 0.007 \\
Foreign firm & {$[1.75]^{*}$} & {$[1.02]$} & {$[0.26]$} \\
& 0.184 & 0.177 & 0.256 \\
Family firm & {$[4.89]^{* * *}$} & {$[4.55]^{* * *}$} & {$[5.17]^{* * *}$} \\
& 0.027 & 0.016 & 0.021 \\
Security costs & {$[1.22]$} & {$[0.64]$} & {$[0.69]$} \\
& 0.010 & 0.010 & 0.010 \\
Debt & {$[2.45]^{* *}$} & {$[2.06]^{*}$} & {$[1.16]$} \\
& 0.022 & 0.014 & 0.026 \\
Audited firm & {$[1.10]$} & {$[0.51]$} & {$[1.28]$} \\
& 0.013 & 0.028 & 0.013 \\
Income via bank & {$[0.66]$} & {$[1.14]$} & {$[0.51]$} \\
& -0.019 & -0.025 & 0.001 \\
International accounting & {$[0.71]$} & {$[0.62]$} & {$[0.03]$} \\
& 0.052 & 0.062 & 0.013 \\
Small firm & {$[1.86]^{*}$} & {$[2.42]^{* *}$} & {$[0.32]$} \\
& -0.019 & 0.000 & -0.024 \\
Age & {$[0.75]$} & {$[0.01]$} & {$[0.59]$} \\
& -0.001 & -0.001 & -0.002 \\
Duration & {$[2.04]^{*}$} & {$[1.98]^{*}$} & {$[2.07]^{* *}$} \\
Collateralized & 0.002 & 0.002 & 0.002 \\
& {$[4.67]^{* * *}$} & {$[4.63]^{* * *}$} & {$[4.70]^{* * *}$} \\
& -0.005 & -0.005 & -0.002 \\
& {$[0.15]$} & {$[0.12]$} & {$[0.06]$} \\
\hline
\end{tabular}




\begin{tabular}{|c|c|c|c|}
\hline Interaction terms: & & Local currency & Pegged exchange \\
\hline Exporter & & earner $\mathbf{X}$ & $\begin{array}{r}\text { rate } \mathbf{X} \\
0.035 \\
{[0.97]}\end{array}$ \\
\hline Sales to multinationals & & & -0.078 \\
\hline Foreign firm & & & $\begin{array}{r}0.139 \\
{[2.44]^{* *}}\end{array}$ \\
\hline Family firm & & $\begin{array}{r}0.025 \\
{[0.77]}\end{array}$ & $\begin{array}{c}-0.012 \\
{[0.26]}\end{array}$ \\
\hline Security costs & & $\begin{array}{l}-0.001 \\
{[0.05]}\end{array}$ & $\begin{array}{c}0.000 \\
{[0.01]}\end{array}$ \\
\hline Debt & & $\begin{array}{c}0.012 \\
{[0.29]}\end{array}$ & $\begin{array}{c}0.009 \\
{[0.25]}\end{array}$ \\
\hline Audited firm & & $\begin{array}{r}-0.044 \\
{[2.09]^{* *}}\end{array}$ & $\begin{array}{r}0.003 \\
{[0.08]}\end{array}$ \\
\hline Income via bank & & $\begin{array}{r}0.013 \\
{[0.30]}\end{array}$ & $\begin{array}{c}0.043 \\
{[0.84]}\end{array}$ \\
\hline International accounting & & $\begin{array}{l}-0.053 \\
{[1.03]}\end{array}$ & $\begin{array}{r}-0.072 \\
{[1.41]}\end{array}$ \\
\hline Small firm & & $\begin{array}{l}-0.056 \\
{[1.53]}\end{array}$ & $\begin{array}{c}-0.003 \\
{[0.06]}\end{array}$ \\
\hline Age & & $\begin{array}{c}0.000 \\
{[0.10]}\end{array}$ & $\begin{array}{c}-0.001 \\
{[1.17]}\end{array}$ \\
\hline Observations & 2,779 & 2,697 & 2,778 \\
\hline R-squared & 0.16 & 0.16 & 0.17 \\
\hline Sector \& country fixed effects & yes & yes & yes \\
\hline Clustered errors & yes & yes & yes \\
\hline
\end{tabular}




\section{Table 9. Macroeconomic determinants of foreign currency borrowing}

The table reports results from probit estimates for our full sample. The dependent variable Forex loan equals one if the firm's last loan is denominated in foreign currency and zero if this loan is in local currency. Each regression includes the firm-specific explanatory variables Exporter, Sales to multinationals, Foreign firm, Family firm, Security costs, Debt, Audited firm, Income via bank, International accounting, Small firm, Age, Duration and Collateralized, as well as six sector dummies. All explanatory variables are defined in Table 1.The table displays the marginal effects calculated at sample means.

\section{Panel A: Without country fixed effects}

T-statistics reported in parentheses are based on standard errors [not adjusted] resp. (adjusted) for clustering at country-level. ${ }^{*}, * *$, and $* * *$ indicate significance at the $10 \%, 5 \%$, and $1 \%$ levels, respectively.

\begin{tabular}{|c|c|c|c|c|}
\hline & $(1)$ & $(2)$ & (3) & $(4)$ \\
\hline Interest diff. - USD & $\begin{array}{r}0.006 \\
{[4.62]^{* * *}} \\
(3.11)^{* * *}\end{array}$ & & & \\
\hline Interest diff. - Euro & & $\begin{array}{r}0.006 \\
{[4.85]^{* * * *}} \\
(3.56)^{* * * *}\end{array}$ & & \\
\hline Interest diff. - loans & & & $\begin{array}{r}0.011 \\
{[4.22] * * *} \\
(3.81)^{* * *}\end{array}$ & \\
\hline Interest diff. - deposits & & & & $\begin{array}{r}0.008 \\
{[3.06]^{* * *}} \\
(1.76)^{*}\end{array}$ \\
\hline Depreciation - USD & $\begin{array}{l}-0.002 \\
{[0.94]} \\
(0.71)\end{array}$ & & $\begin{array}{c}0.000 \\
{[0.16]} \\
(0.15)\end{array}$ & $\begin{array}{r}0.002 \\
{[0.51]} \\
(0.54)\end{array}$ \\
\hline Depreciation. volatility - USD & $\begin{array}{c}0.002 \\
{[1.02]} \\
(0.51)\end{array}$ & & $\begin{array}{c}0.002 \\
{[0.73]} \\
(0.39)\end{array}$ & $\begin{array}{c}0.001 \\
{[0.36]} \\
(0.21)\end{array}$ \\
\hline Depreciation - Euro & & $\begin{array}{r}-0.004 \\
{[2.23]^{* *}} \\
(1.73)^{*}\end{array}$ & $\begin{array}{c}-0.004 \\
{[1.60]} \\
(1.78)^{*}\end{array}$ & $\begin{array}{r}-0.006 \\
{[2.19]^{* *}} \\
(2.88)^{* * *}\end{array}$ \\
\hline Depreciation volatility - Euro & & $\begin{array}{c}0.002 \\
{[0.94]} \\
(0.60)\end{array}$ & $\begin{array}{l}0.000 \\
{[0.08]} \\
(0.07)\end{array}$ & $\begin{array}{c}0.002 \\
{[0.66]} \\
(0.57)\end{array}$ \\
\hline Peg & $\begin{array}{r}0.060 \\
{[3.08]^{* * *}} \\
(1.93)^{*}\end{array}$ & $\begin{array}{r}0.065 \\
{[3.18]^{* * * *}} \\
(1.80)^{*}\end{array}$ & $\begin{array}{c}0.025 \\
{[0.96]} \\
(0.62)\end{array}$ & $\begin{array}{l}0.026 \\
{[1.00]} \\
(0.73)\end{array}$ \\
\hline EU & $\begin{array}{r}-0.092 \\
{[3.65]^{* * *}} \\
(2.12)^{* *}\end{array}$ & $\begin{array}{r}-0.081 \\
{[3.68] * * *} \\
(2.79)^{* * *}\end{array}$ & $\begin{array}{r}-0.087 \\
{[2.88]^{* * *}} \\
(1.66)^{*}\end{array}$ & $\begin{array}{r}-0.104 \\
{[3.26]^{* * *}} \\
(1.72)^{*}\end{array}$ \\
\hline Inflation volatility & $\begin{array}{r}0.017 \\
{[2.38]^{* *}} \\
(1.49) \\
\end{array}$ & $\begin{array}{r}0.018 \\
{[2.59]^{* * *}} \\
(1.61) \\
\end{array}$ & $\begin{array}{r}0.024 \\
{[3.11]^{* * *}} \\
(2.18)^{* *} \\
\end{array}$ & $\begin{array}{r}0.014 \\
{[1.80]^{*}} \\
(1.33) \\
\end{array}$ \\
\hline Observations & 2,584 & 2,584 & 2,058 & 1,868 \\
\hline Firm-level explanatory variables & yes & yes & yes & yes \\
\hline Sector fixed effects & yes & yes & yes & yes \\
\hline Country fixed effects & no & no & no & no \\
\hline
\end{tabular}




\section{Panel B: With country fixed effects}

T-statistics reported in parentheses are based on standard errors [not adjusted] resp. (adjusted) for clustering at country-level. *,**, and *** indicate significance at the $10 \%, 5 \%$, and $1 \%$ levels, respectively.

\begin{tabular}{|c|c|c|c|c|}
\hline & (1) & (2) & (3) & (4) \\
\hline Interest diff. - USD & $\begin{array}{l}0.003 \\
{[1.35]} \\
(1.46)\end{array}$ & & & \\
\hline Interest diff. - Euro & & $\begin{array}{r}0.003 \\
{[1.35]} \\
(1.59)\end{array}$ & & \\
\hline Interest diff. - loans & & & $\begin{array}{l}0.000 \\
{[0.07]} \\
(0.09)\end{array}$ & \\
\hline Interest diff. - deposits & & & & $\begin{array}{r}0.011 \\
{[1.71]^{*}} \\
(3.38)^{* * *}\end{array}$ \\
\hline Depreciation - USD & $\begin{array}{r}0.003 \\
{[1.41]} \\
(1.58)\end{array}$ & & $\begin{array}{r}0.006 \\
{[1.74]^{*}} \\
(1.76)^{*}\end{array}$ & $\begin{array}{r}0.008 \\
{[2.34]^{* *}} \\
(2.85)^{* * * *}\end{array}$ \\
\hline Depreciation. volatility - USD & $\begin{array}{c}-0.004 \\
{[1.44]} \\
(1.45)\end{array}$ & & $\begin{array}{l}-0.006 \\
{[1.31]} \\
(1.21)\end{array}$ & $\begin{array}{r}-0.006 \\
{[1.36]} \\
(1.28)\end{array}$ \\
\hline Depreciation - Euro & & $\begin{array}{l}-0.001 \\
{[0.67]} \\
(0.82)\end{array}$ & $\begin{array}{l}-0.003 \\
{[1.06]} \\
(1.17)\end{array}$ & $\begin{array}{r}-0.005 \\
{[1.68]^{*}} \\
(2.63)^{* * *}\end{array}$ \\
\hline Depreciation volatility - Euro & & $\begin{array}{c}0.002 \\
{[0.67]} \\
(0.89)\end{array}$ & $\begin{array}{c}0.004 \\
{[1.11]} \\
(1.70)^{*}\end{array}$ & $\begin{array}{r}0.004 \\
{[1.03]} \\
(1.52)\end{array}$ \\
\hline $\mathrm{EU}$ & $\begin{array}{r}0.050 \\
{[1.16]} \\
(1.01)\end{array}$ & $\begin{array}{c}0.011 \\
{[0.29]} \\
(0.25)\end{array}$ & $\begin{array}{c}0.042 \\
{[0.76]} \\
(0.62)\end{array}$ & $\begin{array}{r}0.076 \\
{[1.36]} \\
(1.30)\end{array}$ \\
\hline Inflation volatility & $\begin{array}{r}0.032 \\
{[1.83]^{*}} \\
(2.01)^{* *}\end{array}$ & $\begin{array}{r}0.031 \\
{[1.79]^{*}} \\
(2.20)^{* *}\end{array}$ & $\begin{array}{r}0.031 \\
{[1.65]^{*}} \\
(1.72)^{*}\end{array}$ & $\begin{array}{r}0.029 \\
{[1.54]} \\
(1.58)\end{array}$ \\
\hline Observations & 2,584 & 2,584 & 2,057 & 1,866 \\
\hline Firm-level explanatory variables & yes & yes & yes & yes \\
\hline Sector fixed effects & yes & yes & yes & yes \\
\hline Country fixed effects & no & no & no & no \\
\hline
\end{tabular}




\section{Table 10. Macroeconomic determinants: subsample results}

The dependent variable Forex loan equals one if the firm's last loan is denominated in foreign currency and zero if this loan is in local currency. Each regression includes the firm-specific explanatory variables Exporter, Sales to multinationals, Foreign firm, Family firm, Security costs, Debt, Audited firm, Income via bank, International accounting, Small firm, Age, Duration and Collateralized. All explanatory variables are defined in Table 1. Standard errors are adjusted for cluster effects at the country level. T-statistics are reported in parentheses. *,**, and *** indicate significance at the $10 \%, 5 \%$, and $1 \%$ levels, respectively.

\section{Panel A. Interaction effects}

The table reports results from OLS estimates of the interaction effects of our macroeconomic explanatory variables with Local currency earner, EU and CIS respectively for our full sample. Local currency earners are firms that have no export sales, no sales to multinationals, and no majority foreign owner and are situated in weakly dollarized countries. Foreign currency earners are all other firms. Weakly dollarized countries have a mean share of foreign currency deposits in the banking system of $50 \%$ or less for the observation period. $E U$ : firms located in countries which have completed negotiations to join the European Union. Non-EU: all other firms. CIS: firms located in countries which are members of the Commonwealth of Independent States. Non-CIS: all other firms. Each regression also includes the main effects of each macroeconomic variable, as well as firm-level explanatory variables.

\begin{tabular}{|c|c|c|c|c|c|c|}
\hline & $(1)$ & $(2)$ & (3) & $(4)$ & $(5)$ & (6) \\
\hline Interaction term with & \multicolumn{2}{|c|}{ Local currency earner } & \multicolumn{2}{|c|}{$\boldsymbol{E} \boldsymbol{U}$} & \multicolumn{2}{|c|}{ CIS } \\
\hline \multirow[t]{2}{*}{ Interest diff. - USD } & -0.002 & & -0.005 & & 0.002 & \\
\hline & {$[0.74]$} & & {$[1.09]$} & & {$[0.42]$} & \\
\hline \multirow[t]{2}{*}{ Depreciation - USD } & 0.002 & & -0.001 & & -0.008 & \\
\hline & {$[0.43]$} & & {$[0.21]$} & & {$[1.15]$} & \\
\hline \multirow[t]{2}{*}{ Deprec. volatility - USD } & 0.007 & & 0.001 & & 0.004 & \\
\hline & {$[1.45]$} & & {$[0.23]$} & & {$[0.71]$} & \\
\hline \multirow[t]{2}{*}{ Interest diff. - Euro } & & 0.000 & & -0.004 & & -0.001 \\
\hline & & {$[0.04]$} & & [1.39] & & {$[0.17]$} \\
\hline \multirow[t]{2}{*}{ Depreciation - Euro } & & 0.002 & & 0.007 & & -0.005 \\
\hline & & {$[1.08]$} & & {$[2.34]^{* *}$} & & {$[1.77]^{*}$} \\
\hline \multirow[t]{2}{*}{ Deprec. volatility - Euro } & & -0.004 & & -0.002 & & -0.001 \\
\hline & & {$[1.34]$} & & {$[0.42]$} & & {$[0.31]$} \\
\hline \multirow{2}{*}{ EU } & -0.103 & -0.043 & & & & \\
\hline & {$[2.37]^{* *}$} & {$[1.75]^{*}$} & & & & \\
\hline \multirow[t]{2}{*}{ Inflation volatility } & -0.016 & 0.015 & 0.096 & 0.106 & 0.013 & 0.008 \\
\hline & {$[0.59]$} & {$[0.71]$} & {$[1.01]$} & {$[1.00]$} & {$[0.18]$} & {$[0.11]$} \\
\hline Observations & 2,584 & 2,584 & 2,584 & 2,584 & 2,584 & 2,584 \\
\hline $\mathrm{R}$ squared & 0.16 & 0.16 & 0.16 & 0.16 & 0.16 & 0.16 \\
\hline Firm-level variables & yes & yes & yes & yes & yes & yes \\
\hline Sector fixed effects & yes & yes & yes & yes & yes & yes \\
\hline Country fixed effects & yes & yes & yes & yes & yes & yes \\
\hline Clustered errors & yes & yes & yes & yes & yes & yes \\
\hline
\end{tabular}


Panel B: Country-specific regressions

Panel $\mathrm{C}$ replicates the regressions from column 1 (USD) and column 2 (Euro) of Panel A in Table 9 for each country separately. Regressions for Azerbaijan, Bosnia, Czech Republic, Estonia, Slovak Republic, Tajikistan and Uzbekistan could not be carried out due to lack of country-level explanatory variables or insufficient variation in firm-level data. All regressions omit sector dummies.

\begin{tabular}{|c|c|c|c|c|c|c|c|}
\hline \multirow{2}{*}{\multicolumn{2}{|c|}{$\begin{array}{l}\text { Country } \\
\text { (Observations) }\end{array}$}} & \multicolumn{3}{|c|}{$\overline{\text { USD }}$} & \multicolumn{3}{|c|}{ Euro } \\
\hline & & $\begin{array}{r}\text { Interest } \\
\text { Diff. }\end{array}$ & Deprec. & $\begin{array}{r}\text { Deprec. } \\
\text { Volatility }\end{array}$ & $\begin{array}{r}\text { Interest } \\
\text { Diff. }\end{array}$ & Deprec. & $\begin{array}{r}\text { Deprec. } \\
\text { Volatility }\end{array}$ \\
\hline \multirow[t]{2}{*}{ Albania } & (70) & -0.003 & -0.003 & 0.013 & 0.000 & 0.000 & 0.000 \\
\hline & & {$[0.53]$} & [1.14] & {$[2.25]^{* *}$} & [1.56] & {$[2.17]^{* *}$} & {$[0.65]$} \\
\hline \multirow[t]{2}{*}{ Armenia } & (135) & -0.009 & 0.045 & 0.029 & 0.009 & 0.004 & 0.031 \\
\hline & & {$[0.48]$} & [1.28] & {$[0.37]$} & {$[0.66]$} & [0.39] & [0.94] \\
\hline \multirow[t]{2}{*}{ Belarus } & (69) & 0.013 & 0.024 & -1.074 & -0.011 & -0.018 & 0.013 \\
\hline & & [0.86] & [0.30] & {$[2.09]^{* *}$} & {$[0.68]$} & [1.19] & {$[0.31]$} \\
\hline \multirow[t]{2}{*}{ Bulgaria } & $(90)$ & 0.088 & -0.015 & -0.016 & 0.181 & -0.034 & -0.323 \\
\hline & & [0.96] & [0.83] & {$[0.91]$} & [0.88] & {$[0.56]$} & [1.19] \\
\hline \multirow[t]{2}{*}{ Croatia } & (101) & 0.013 & 0.026 & 0.017 & 0.030 & 0.020 & -0.011 \\
\hline & & [0.44] & {$[2.01]^{* *}$} & {$[0.35]$} & [0.91] & [1.05] & {$[0.25]$} \\
\hline \multirow[t]{2}{*}{ Georgia } & (45) & -0.012 & -0.208 & -0.514 & 0.007 & 0.006 & 0.051 \\
\hline & & [1.49] & {$[2.44]^{* *}$} & {$[2.52]^{* *}$} & [0.87] & [0.29] & [0.89] \\
\hline \multirow[t]{2}{*}{ Hungary } & (220) & 0.046 & 0.005 & -0.018 & 0.049 & -0.011 & -0.070 \\
\hline & & [1.35] & [0.57] & {$[1.60]$} & {$[1.90]^{*}$} & [0.70] & {$[2.00]^{* *}$} \\
\hline \multirow[t]{2}{*}{ Kazakhstan } & (227) & 0.028 & 0.008 & -0.059 & -0.047 & -0.001 & 0.004 \\
\hline & & [0.41] & {$[0.32]$} & {$[0.87]$} & [0.42] & [0.11] & {$[0.31]$} \\
\hline \multirow[t]{2}{*}{ Kyrgyzstan } & (63) & 0.067 & -0.031 & 0.008 & 0.098 & 0.006 & 0.025 \\
\hline & & [1.27] & [1.04] & {$[0.28]$} & {$[1.70]^{*}$} & [0.45] & [1.15] \\
\hline \multirow[t]{2}{*}{ Latvia } & (65) & -0.105 & 0.009 & -0.062 & -0.011 & 0.016 & -0.101 \\
\hline & & {$[1.86]^{*}$} & {$[0.60]$} & {$[1.51]$} & {$[0.28]$} & [0.98] & {$[2.27]^{* *}$} \\
\hline \multirow[t]{2}{*}{ Lithuania } & (63) & -0.129 & 0.011 & -0.010 & 0.040 & 0.013 & -0.122 \\
\hline & & [1.47] & [1.01] & {$[1.03]$} & [0.58] & {$[0.50]$} & {$[0.96]$} \\
\hline \multirow[t]{2}{*}{ Macedonia } & (32) & -0.355 & -0.104 & 0.065 & -0.182 & 0.041 & 0.087 \\
\hline & & {$[1.28]$} & [1.28] & {$[1.15]$} & {$[0.76]$} & {$[0.24]$} & {$[0.25]$} \\
\hline \multirow[t]{2}{*}{ Moldova } & (122) & 0.013 & 0.018 & -0.029 & 0.007 & 0.004 & -0.006 \\
\hline & & [0.92] & [1.03] & {$[0.62]$} & [0.49] & [0.63] & {$[0.24]$} \\
\hline \multirow[t]{2}{*}{ Poland } & (280) & 0.011 & 0.004 & 0.002 & 0.013 & 0.005 & 0.001 \\
\hline & & {$[0.98]$} & [1.10] & {$[0.12]$} & [0.41] & {$[0.60]$} & {$[0.06]$} \\
\hline \multirow[t]{2}{*}{ Romania } & (224) & -0.001 & 0.012 & 0.016 & 0.001 & -0.004 & -0.018 \\
\hline & & [0.11] & {$[1.25]$} & {$[1.06]$} & [0.07] & [0.42] & {$[0.79]$} \\
\hline \multirow[t]{2}{*}{ Russia } & (162) & 0.009 & -0.006 & 0.007 & 0.001 & 0.011 & -0.002 \\
\hline & & {$[0.56]$} & [0.60] & {$[0.12]$} & [0.08] & [1.62] & {$[0.24]$} \\
\hline \multirow[t]{2}{*}{ Serbia } & (106) & 0.098 & -0.007 & -0.003 & 0.105 & 0.019 & 0.052 \\
\hline & & {$[1.87]^{*}$} & {$[0.46]$} & {$[0.18]$} & {$[2.23]^{* *}$} & [0.58] & {$[0.77]$} \\
\hline \multirow[t]{2}{*}{ Slovenia } & (112) & -0.032 & -0.006 & 0.014 & -0.026 & -0.055 & 0.026 \\
\hline & & {$[0.41]$} & [0.35] & {$[0.39]$} & [0.57] & [1.10] & {$[0.22]$} \\
\hline \multirow[t]{2}{*}{ Ukraine } & (209) & -0.014 & 0.168 & 0.149 & -0.009 & -0.005 & -0.003 \\
\hline & & {$[1.75]^{*}$} & {$[0.54]$} & [0.69] & [1.06] & {$[0.62]$} & {$[0.18]$} \\
\hline
\end{tabular}




\section{Table 11. Institutional determinants of foreign currency borrowing}

The table reports results from probit estimates. The dependent variable Forex loan equals one if the firm's last loan is denominated in foreign currency and zero if this loan is in local currency. Each regression includes the firm-specific explanatory variables Exporter, Sales to multinationals, Foreign firm, Family firm, Security costs, Debt, Audited firm, Income via bank, International accounting, Small firm, Age, Duration and Collateralized, as well as six sector dummies. All explanatory variables are defined in Table 1.The table displays the marginal effects calculated at sample means. T-statistics are reported in parentheses. $* *$, and $* * *$ indicate significance at the $10 \%, 5 \%$, and $1 \%$ levels, respectively.

\begin{tabular}{|c|c|c|c|c|}
\hline & (1) & (2) & (3) & (4) \\
\hline \multirow[t]{2}{*}{ Interest diff. - USD } & -0.001 & -0.001 & & \\
\hline & {$[0.40]$} & [0.31] & & \\
\hline \multirow[t]{2}{*}{ Depreciation - USD } & 0.002 & 0.002 & & \\
\hline & [0.48] & [0.57] & & \\
\hline \multirow{2}{*}{ Depreciation volatility - USD } & -0.003 & -0.003 & & \\
\hline & [1.03] & [1.26] & & \\
\hline \multirow[t]{2}{*}{ Interest diff. - Euro } & & & -0.001 & -0.001 \\
\hline & & & [0.49] & {$[0.40]$} \\
\hline \multirow{2}{*}{ Depreciation - Euro } & & & -0.003 & -0.003 \\
\hline & & & {$[0.87]$} & {$[1.25]$} \\
\hline \multirow[t]{2}{*}{ Depreciation volatility - Euro } & & & 0.005 & 0.005 \\
\hline & & & [1.11] & {$[1.24]$} \\
\hline \multirow[t]{2}{*}{ Peg } & 0.018 & 0.018 & 0.04 & 0.04 \\
\hline & {$[0.52]$} & [0.34] & [1.22] & {$[0.93]$} \\
\hline \multirow[t]{2}{*}{ EU } & 0 & 0 & -0.031 & -0.031 \\
\hline & {$[0.01]$} & [0.01] & {$[0.65]$} & {$[0.54]$} \\
\hline \multirow[t]{2}{*}{ Inflation volatility } & 0.024 & 0.024 & 0.022 & 0.022 \\
\hline & {$[2.07] * *$} & {$[1.73]^{*}$} & {$[2.00] * *$} & [1.75] ] \\
\hline \multirow{2}{*}{ Foreign banks } & 0.002 & 0.002 & 0.002 & 0.002 \\
\hline & {$[2.80]^{* * *}$} & {$[4.48]^{* * *}$} & {$[2.83]^{* * *}$} & {$[4.88]^{* * *}$} \\
\hline \multirow[t]{2}{*}{ Enterprise reform } & -0.254 & -0.254 & -0.265 & -0.265 \\
\hline & {$[4.31]^{* * *}$} & {$[3.64]^{* * *}$} & {$[4.44]^{* * *}$} & {$[3.89]^{* * *}$} \\
\hline \multirow{2}{*}{ Forex deposits } & -0.003 & -0.003 & -0.003 & -0.003 \\
\hline & {$[2.80]^{* * *}$} & {$[2.00]^{* *}$} & {$[2.11]^{* *}$} & {$[1.68]^{*}$} \\
\hline \multirow[t]{2}{*}{ CIS } & -0.074 & -0.074 & -0.082 & -0.082 \\
\hline & [1.17] & [0.91] & [1.27] & [1.02] \\
\hline \multirow[t]{2}{*}{ Forward fx market } & -0.074 & -0.074 & -0.044 & -0.044 \\
\hline & [1.21] & [1.23] & {$[0.72]$} & {$[0.75]$} \\
\hline \multirow[t]{2}{*}{ Capital controls } & -0.058 & -0.058 & -0.067 & -0.067 \\
\hline & {$[1.73]^{*}$} & {$[2.16]^{* *}$} & {$[2.06]^{* *}$} & {$[2.51]^{* *}$} \\
\hline \multirow[t]{2}{*}{ Open fx position } & 0.005 & 0.005 & 0.004 & 0.004 \\
\hline & {$[2.52]^{* *}$} & {$[3.01]^{* * *}$} & {$[1.96]^{* *}$} & {$[2.32]^{* *}$} \\
\hline Observations & 1,493 & 1,493 & 1,493 & 1,493 \\
\hline Firm-level variables & yes & yes & yes & yes \\
\hline Sector fixed effects & yes & yes & yes & yes \\
\hline Country fixed effects & no & no & no & no \\
\hline Clustered errors & no & yes & no & yes \\
\hline
\end{tabular}




\section{References}

Allayannis, George, Gregory W. Brown, and Leora F. Klapper, 2003, Capital Structure and Financial Risk: Evidence from Foreign Debt Use in East Asia, Journal of Finance 58, 2667-2709.

Allayannis, George, and Eli Ofek, 2001, Exchange Rate Exposure, Hedging, and the Use of Foreign Currency Derivatives, Journal of International Money and Finance 20, 273-296.

Basso, Henrique S., Oscar Calvo-Gonzalez, and Marius Jurgilas, 2007, Financial Dollarization and the Role of Banks and Interest Rates, (European Central Bank, Frankfurt), Working Paper 748.

Benavente, Jose Miguel, Christian A. Johnson, and Felipe G. Morande, 2003, Debt Composition and Balance Sheet Effects of Exchange Rate Depreciations: A Firm-Level Analysis for Chile, Emerging Markets Review 4, 397-416.

Berger, A. N., M. Espinosa-Vega, W. S. Frame, and N. M. Miller, 2005, Debt Maturity, Risk, and Asymmetric Information, Journal of Finance 60, 2895-2924.

Berger, A. N., and G. F. Udell, 1998, The Economics of Small Business Finance: the Roles of Private Equity and Debt Markets in the Financial Growth Cycle, Journal of Banking and Finance 22, 613-673.

Besancenot, Damien, and Radu Vranceanu, 2004, Excessive Liability Dollarization in a Simple Signaling Model, (ESSEC, Paris), Working Paper 04001.

Black, Lamont, 2006, Insider Rates vs Outsider Rates in Bank Lending, (Federal Reserve Board, Washington), Mimeo

Bodnar, Gordon M., Gregory S. Hayt, and Richard C. Marston, 1998, 1998 Wharton Survey of Financial Risk Management by US Nonfinancial Firms, Financial Management 27, 70-91.

Boot, A. W. A., and A. V. Thakor, 2000, Can Relationship Banking Survive Competition?, Journal of Finance 55, 679-713.

Booth, L. V., A. Aivazian, A. Demirgüç-Kunt, and V. Maksimovic, 2001, Capital Structures in Developing Countries, Journal of Finance 56, 87-130.

Børsum, Øystein G., and Bernt Arne Ødegaard, 2005, Currency Hedging in Norwegian Non-Financial firms, Norges Bank Economic Bulletin 133-144.

Briggs, Phil, 2004, Currency Hedging by Exporters and Importers, Reserve Bank of New Zealand Bulletin 67, 17-27.

Brown, Gregory W., 2001, Managing Foreign Exchange Risk with Derivatives, Journal of Financial Economics 60, 401-448.

Brown, Martin, Tullio Jappelli, and Marco Pagano, 2008, Information Sharing and Credit Market Performance: Firm-Level Evidence from Transition Countries, Journal of Financial Intermediation Forthcoming.

Brown, Martin, Steven Ongena, and Pinar Yesin, 2008, Currency Denomination of Bank Loans: Evidence from Small Firms in Transition Countries, (CentER, Tilburg), Working Paper 16.

Brown, Martin, Maria Clara Rueda Maurer, Tamara Pak, and Nurlanbek Tynaev, 2007, Banking Sector Reform and Interest Rates in Transition Economies: Bank-Level Evidence from Kyrgyzstan, (Swiss National Bank, Zurich), Working Paper 7.

Caballero, Ricardo, and Arvid Krishnamurthy, 2003, Excessive Dollar Debt: Financial Development and Underinsurance, Journal of Finance 58, 867-894.

Calvo, G. A., 2001, Capital Markets and the Exchange Rate with Special Reference to the Dollarization Debate in Latin America, Journal of Money. Credit, and Banking 33, 312-334.

Clark, Ephraim, and Amrit Judge, 2007, The Determinants of Foreign Currency Hedging: Does Foreign Currency Debt Induce a Bias?, European Financial Management Forthcoming.

Conesa, Labastida, 1997, Exchange Rate Risk and the Debt Composition of Mexican Firms, Economics (MIT, Boston MA).

Cowan, Kevin, 2006, Firm Level Determinants of Dollar Debt?, (Central Bank of Chile, Santiago), Mimeo

Cowan, Kevin, Erwin Hansen, and Luis Oscar Herrera, 2005, Currency Mismatches, Balance Sheet Effects and Hedging in Chilean Nonfinancial Corporations, (Central Bank of Chile, Santiago), Working Paper 346.

Degryse, H., and S. Ongena, 2007, The Impact of Competition on Bank Orientation, Journal of Financial Intermediation 16, 399-424.

Detragiache, Enrica, Thierry Tressel, and Poonam Gupta, 2008, Foreign Banks in Poor Countries: Theory and Evidence, Journal of Finance Forthcoming. 
Diamond, Douglas W., 1984, Financial Intermediation and Delegated Monitoring, Review of Economic Studies 51, 393-414.

Diamond, Douglas W., 1991, Monitoring and Reputation: the Choice between Bank Loans and Privately Placed Debt, Journal of Political Economy 99, 689-721.

Dollar, David, and Mary Hallward-Driemeier, 2000, Crisis, Adjustment, and Reform in Thailand's Industrial Firms, World Bank Research Observer 15, 1-22.

Egli, Dominik, Steven Ongena, and David C. Smith, 2006, On the Sequencing of Projects, Reputation Building, and Relationship Finance, Finance Research Letters 3, 23-39.

Elsas, R., 2005, Empirical Determinants of Relationship Lending, Journal of Financial Intermediation 14, 32 57.

Engel, Charles, 1996, The Forward Discount Anomaly and the Risk Premium: A Survey of Recent Evidence, Journal of Empirical Finance 3, 123-192.

Engel, Charles, 2006, Equivalence Results for Optimal Pass-Through, Optimal Indexing to Exchange Rates, and Optimal Choice of Currency for Export Pricing, Journal of the European Economic Association Forthcoming.

Esho, Neil, Ian G. Sharpe, and Kristian H. Webster, 2007, Hedging and Choice of Currency Denomination in International Syndicated Loan Markets, Pacific-Basin Finance Journal 15, 195-212.

European Central Bank, 2006. EU Banking Sector Stability (Frankfurt).

Freixas, Xavier, and Jean Charles Rochet, 2008. Microeconomics of Banking (MIT Press, Cambridge MA).

Friberg, Richard, and Fredrik Wilander, 2008, The Currency Denomination of Exports - A Questionnaire Study, Journal of International Economics 75, 54-69.

Froot, Kenneth A., David. S. Scharfstein, and Jeremy C. Stein, 1993, Risk Management: Coordinating Corporate Investment and Financing Policies, Journal of Finance 48, 1629-1658.

Froot, Kenneth A., and Richard H. Thaler, 1990, Anomalies: Foreign Exchange, Journal of Economic Perspectives 4, 179-192.

Galati, Gabriele, Alexandra Heath, and Patrick McGuire, 2007, Evidence of Carry Trade Activity, Bank for International Settlements Quarterly Review 33, 27-41.

Galindo, Arturo, Ugo Panizza, and Fabio Schiantarelli, 2003, Debt Composition and Balance Sheet Effects of Currency Depreciation: A Summary of the Micro Evidence, Emerging Markets Review 4, 330-339.

Gelos, Gaston R., 2003, Foreign Currency Debt in Emerging Markets: Firm-Level Evidence from Mexico, Economics Letters 78, 323-327.

Giannetti, Mariassunta, and Steven Ongena, 2008, Financial Integration and Firm Performance: Evidence from Foreign Bank Entry in Emerging Markets, Review of Finance Forthcoming.

Giannetti, Mariassunta, and Steven Ongena, 2008, "Lending by Example": Direct and Indirect Effects of Foreign Bank Presence in Emerging Markets, (CentER - Tilburg University, Tilburg NL), Mimeo

Goswami, Gautam, and Milind M. Shrikhande, 2001, Economic Exposure and Debt Financing Choice, Journal of Multinational Financial Management 11, 39-58.

Graham, J. R., and C. R. Harvey, 2001, The Theory and Practice of Corporate Finance: Evidence from the Field, Journal of Financial Economics 60, 187-243.

Haiss, Peter, Andreas Paulhart, and Wolfgang Rainer, 2008, Do Foreign Banks Raise the Risk of Foreign currency Risk Taking in Central and Eastern Europe?, (Vienna University of Economics and Business Administration, Vienna), Working Paper

Hauswald, R., and R. Marquez, 2006, Competition and Strategic Information Acquisition in Credit Markets, Review of Financial Studies 19, 967-1000.

Hodrick, Robert J., 1987. The Empirical Evidence on the Efficiency of Forward and Futures Foreign Exchange Markets (Harwood Academic Publishers, Chur).

Isard, Peter, 2006, Uncovered Interest Parity, (International Monetary Fund, Washington D.C.), Working Paper 96.

Ize, Alain, and Eduardo Levy-Yeyati, 2003, Financial Dollarization, Journal of International Economics 59, 323-347.

Jeanne, Olivier, 1999, Foreign Currency Debt and Signaling, (International Monetary Fund., Washington DC), Mimeo

Jeanne, Olivier, 2000, Foreign Currency Debt and the Global Financial Architecture, European Economic Review 44, 719-727.

Kamil, Herman, 2008, How Do Exchange Rate Regimes Affect Firms' Incentives to Hedge Exchange Rate Risk?, (International Monetary Fund, Washington DC), Mimeo 
Kamil, Herman, and Bennett Sutton, 2008, Corporate Vulnerability: Have Firms Reduced Their Exposure to Currency Risk, in International Monetary Fund, ed.: Regional Economic Outlook: Western Hemisphere (International Monetary Fund, Washington DC).

Kedia, Simi, and Abon Mozumdar, 2003, Foreign Currency-Denominated Debt: An Empirical Examination, Journal of Business 76, 521-546.

Keloharju, Matti, and Mervi Niskanen, 2001, Why Do Firms Raise Foreign Currency Denominated Debt?, European Financial Management 7, 481-496.

Lewis, Karen, 1995, Chapter 37: Puzzles in International Financial Markets, in Gene Grossman, and Kenneth Rogoff, eds.: Handbook of International Economics, Vol. III (Elsevier, North-Holland).

Luca, Alina, and Iva Petrova, 2008, What Drives Credit Dollarization in Transition Economies?, Journal of Banking and Finance 32, 858-869.

Mester, Loretta J., Leonard Nakamura, and Micheline Renault, 2007, Transactions Accounts and Loan Monitoring, Review of Financial Studies 20, 529-556.

Mian, Shezhad L., 1996, Evidence on Corporate Hedging Policy, Journal of Financial and Quantitative Analysis 31, 419-439.

Norden, Lars, and Martin Weber, 2007, Checking Account Information and Credit Risk of Bank Customers, (University of Mannheim, Mannheim), Mimeo

O'Connell, Sandra, 2005, Currency Game Is Risky for the Smaller Players, Sunday Times.

Ortiz-Molina, Hernan, and M. Fabiana Penas, 2008, Lending to Small Businesses: The Role of Loan Maturity in Addressing Information Problems, Small Business Economics 30, 361-383.

Petersen, M. A., and R. G. Rajan, 1995, The Effect of Credit Market Competition on Lending Relationships, Quarterly Journal of Economics 110, 406-443.

Pistor, K., M. Raiser, and S. Gelfer, 2000, Law and Finance in Transition Economies, Economics of Transition 8, 325-368.

Rajan, R. G., 1992, Insiders and Outsiders: the Choice between Informed and Arm's-Length Debt, Journal of Finance 47, 1367-1400.

Rajan, Raghuram G., and L. Zingales, 1995, What Do We Know about Capital Structure? Some Evidence from International Data, Journal of Finance 50, 1421-1460.

Rey, Hélène, 2001, International Trade and Currency Exchange, Review of Economic Studies 68, 443-464.

Rosenberg, Christoph B., and Marcel Tirpak, 2008, Determinants of Foreign Currency Borrowing in the New Member States of the EU, (International Monetary Fund, Washington DC), Working Paper 08/173.

Ross, S. A., 1977, The Determination of Financial Structure: the Incentive-Signaling Approach, Bell Journal of Economics 8, 1-30.

Rueda Maurer, Maria Clara, 2008, Foreign bank entry, institutional development and credit access: firm-level evidence from 22 transition countries, (Swiss National Bank, Zurich), Working Paper 4.

Sharpe, S. A., 1990, Asymmetric Information, Bank Lending and Implicit Contracts: a Stylized Model of Customer Relationships, Journal of Finance 45, 1069-1087.

Sorsa, Piritta, Bas B. Bakker, Christoph Duenwald, Andrea M. Maechler, and Andrew Tiffin, 2007, Vulnerabilities in Emerging Southeastern Europe-How Much Cause for Concern?, (International Monetary Fund, Washington DC), Working Paper 236.

Stein, J., 2002, Information Production and Capital Allocation: Decentralized versus Hierarchical Firms, Journal of Finance 57, 1891-1922.

Stulz, Rene M., 1984, Optimal Hedging Policies, Journal of Financial and Quantitative Analysis 19, 127-140.

Tirole, Jean, 2003, Inefficient Foreign Borrowing: A Dual- and Common-Agency Perspective, American Economic Review 93, 1678-1702.

Titman, S., and B. Trueman, 1986, Information Quality and New Issue Valuation, Journal of Accounting and Economics 8, 159-172.

Townsend, Robert M., 1979, Optimal Contracts and Competitive Markets with Costly State Verification, Journal of Economic Theory 21, 265-293.

Tsamenyi, Mathew, and Darina Skliarova, 2005, International Cash Management Practices in a Russian Multinational, Managerial Finance 31, 48-64.

Viaene, Jean-Marie, and Casper G. de Vries, 1992, On the Design of Invoicing Practises in International Trade, Open Economies Review 3, 133-142.

von Thadden, E. L., 2004, Asymmetric Information, Bank Lending, and Implicit Contracts: the Winner's Curse, Finance Research Letters 1, 11-23.

Ziaul Hoque, Mohammad, 2003, Flawed Public Policies and Industrial Loan Defaults: The Case of Bangladesh, Managerial Finance 29, 98-121. 


\section{Swiss National Bank Working Papers published since 2004:}

2004-1 Samuel Reynard: Financial Market Participation and the Apparent Instability of Money Demand

2004-2 Urs W. Birchler and Diana Hancock: What Does the Yield on Subordinated Bank Debt Measure?

2005-1 Hasan Bakhshi, Hashmat Khan and Barbara Rudolf: The Phillips curve under state-dependent pricing

2005-2 Andreas M. Fischer: On the Inadequacy of Newswire Reports for Empirical Research on Foreign Exchange Interventions

2006-1 Andreas M. Fischer: Measuring Income Elasticity for Swiss Money Demand: What do the Cantons say about Financial Innovation?

2006-2 Charlotte Christiansen and Angelo Ranaldo: Realized Bond-Stock Correlation: Macroeconomic Announcement Effects

2006-3 Martin Brown and Christian Zehnder: Credit Reporting, Relationship Banking, and Loan Repayment

2006-4 Hansjörg Lehmann and Michael Manz: The Exposure of Swiss Banks to Macroeconomic Shocks - an Empirical Investigation

2006-5 Katrin Assenmacher-Wesche and Stefan Gerlach: Money Growth, Output Gaps and Inflation at Low and High Frequency: Spectral Estimates for Switzerland

2006-6 Marlene Amstad and Andreas M. Fischer: Time-Varying Pass-Through from Import Prices to Consumer Prices: Evidence from an Event Study with Real-Time Data

2006-7 Samuel Reynard: Money and the Great Disinflation

2006-8 Urs W. Birchler and Matteo Facchinetti: Can bank supervisors rely on market data? A critical assessment from a Swiss perspective

2006-9 Petra Gerlach-Kristen: A Two-Pillar Phillips Curve for Switzerland

2006-10 Kevin J. Fox and Mathias Zurlinden: On Understanding Sources of Growth and Output Gaps for Switzerland

2006-11 Angelo Ranaldo: Intraday Market Dynamics Around Public Information Arrivals

2007-1 Andreas M. Fischer, Gulzina Isakova and Ulan Termechikov: Do FX traders in Bishkek have similar perceptions to their London colleagues? Survey evidence of market practitioners' views 
2007-2 Ibrahim Chowdhury and Andreas Schabert: Federal Reserve Policy viewed through a Money Supply Lens

2007-3 Angelo Ranaldo: Segmentation and Time-of-Day Patterns in Foreign Exchange Markets

2007-4 Jürg M. Blum: Why `Basel II’ May Need a Leverage Ratio Restriction

2007-5 Samuel Reynard: Maintaining Low Inflation: Money, Interest Rates, and Policy Stance

2007-6 Rina Rosenblatt-Wisch: Loss Aversion in Aggregate Macroeconomic Time Series

2007-7 Martin Brown, Maria Rueda Maurer, Tamara Pak and Nurlanbek Tynaev: Banking Sector Reform and Interest Rates in Transition Economies: Bank-Level Evidence from Kyrgyzstan

2007-8 Hans-Jürg Büttler: An Orthogonal Polynomial Approach to Estimate the Term Structure of Interest Rates

2007-9 Raphael Auer: The Colonial Origins Of Comparative Development: Comment. A Solution to the Settler Mortality Debate

2007-10 Franziska Bignasca and Enzo Rossi: Applying the Hirose-Kamada filter to Swiss data: Output gap and exchange rate pass-through estimates

2007-11 Angelo Ranaldo and Enzo Rossi: The reaction of asset markets to Swiss National Bank communication

2007-12 Lukas Burkhard and Andreas M. Fischer: Communicating Policy Options at the Zero Bound

2007-13 Katrin Assenmacher-Wesche, Stefan Gerlach, and Toshitaka Sekine: Monetary Factors and Inflation in Japan

2007-14 Jean-Marc Natal and Nicolas Stoffels: Globalization, markups and the natural rate of interest

2007-15 Martin Brown, Tullio Jappelli and Marco Pagano: Information Sharing and Credit: Firm-Level Evidence from Transition Countries

2007-16 Andreas M. Fischer, Matthias Lutz and Manuel Wälti: Who Prices Locally? Survey Evidence of Swiss Exporters

2007-17 Angelo Ranaldo and Paul Söderlind: Safe Haven Currencies 
2008-1 Martin Brown and Christian Zehnder: The Emergence of Information Sharing in Credit Markets

2008-2 Yvan Lengwiler and Carlos Lenz: Intelligible Factors for the Yield Curve

2008-3 Katrin Assenmacher-Wesche and M. Hashem Pesaran: Forecasting the Swiss Economy Using VECX* Models: An Exercise in Forecast Combination Across Models and Observation Windows

2008-4 Maria Clara Rueda Maurer: Foreign bank entry, institutional development and credit access: firm-level evidence from 22 transition countries

2008-5 Marlene Amstad and Andreas M. Fischer: Are Weekly Inflation Forecasts Informative?

2008-6 Raphael Auer and Thomas Chaney: Cost Pass Through in a Competitive Model of Pricing-to-Market

2008-7 Martin Brown, Armin Falk and Ernst Fehr: Competition and Relational Contracts: The Role of Unemployment as a Disciplinary Device

2008-8 Raphael Auer: The Colonial and Geographic Origins of Comparative Development

2008-9 Andreas M. Fischer and Angelo Ranaldo: Does FOMC News Increase Global FX Trading?

2008-10 Charlotte Christiansen and Angelo Ranaldo: Extreme Coexceedances in New EU Member States' Stock Markets

2008-11 Barbara Rudolf and Mathias Zurlinden: Measuring capital stocks and capital services in Switzerland

2008-12 Philip Sauré: How to Use Industrial Policy to Sustain Trade Agreements

2008-13 Thomas Bolli and Mathias Zurlinden: Measuring growth of labour quality and the quality-adjusted unemployment rate in Switzerland

2008-14 Samuel Reynard: What Drives the Swiss Franc?

2008-15 Daniel Kaufmann: Price-Setting Behaviour in Switzerland - Evidence from CPI Micro Data

2008-16 Katrin Assenmacher-Wesche and Stefan Gerlach: Financial Structure and the Impact of Monetary Policy on Asset Prices

2008-17 Ernst Fehr, Martin Brown and Christian Zehnder: On Reputation: A Microfoundation of Contract Enforcement and Price Rigidity 
2008-18 Raphael Auer and Andreas M. Fischer: The Effect of Low-Wage Import Competition on U.S. Inflationary Pressure

2008-19 Christian Beer, Steven Ongena and Marcel Peter: Borrowing in Foreign Currency: Austrian Households as Carry Traders

2009-1 Thomas Bolli and Mathias Zurlinden: Measurement of labor quality growth caused by unobservable characteristics

2009-2 Martin Brown, Steven Ongena and Pinar Yeșin: Foreign Currency Borrowing by Small Firms 
Swiss National Bank Working Papers are also available at www.snb.ch, section Publications/Research Subscriptions or individual issues can be ordered at Swiss National Bank, Fraumünsterstrasse 8, CH-8022 Zurich, fax+41 4463181 14, E-mail library@snb.ch 